صورة المجتمع في نصوص هسرح الطفل المستــلهمة هن النزاث عند السيد حافظ

\author{
إعلاد \\ ه/ هـدك سعيد عبد العليم \\ مدرس بكلية التربية النوعية \\ جامعة كفرالشيخ
}

مجلة بحوث التربية النوعية ـ جامعة المنصورة

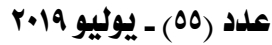


مجلة بحوث التربية النوعية - علدد

\section{صورة المجتمع في نصوص هسرح الطفل المستــلهمة هن التراث عند السيد حافظ}

$$
\begin{aligned}
& \text { (إعداد - - ماد } \\
& \text { م/هـدسعـد عبد العـليم }
\end{aligned}
$$

anill

• مشكلة البحث: تبلورت مشكلة هذا البحث حول التساؤل التالي: ما هي صورة المجتهـع ِِّ نصوص

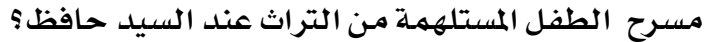

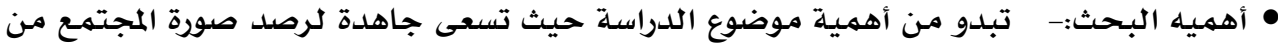

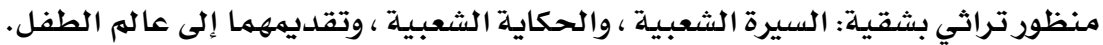
• أهداف البحث: التعرف على صورة المجتمع عِّ نصوص مسرح الطفل المستلهمـة من التراث عند السيد حافظ. • نوع البحث ومنهجهـ: يعد البحث من البحوث الوصفية يِّ تحليل المضمون. • طريقة اختيار العينة: اختارت الباحثة النصين المسرحيين بالطريقة العمدية.

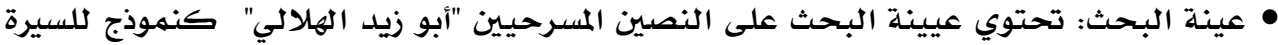

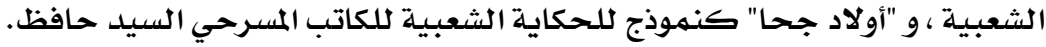

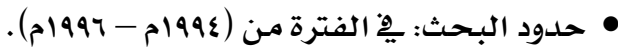

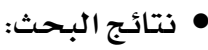

- استعان السيد حافظ بالتراث؛ لأنه وجد فيه مادة خصبة تتميز بالمرونة والثراء ، والمواقف التي

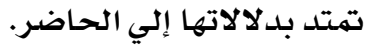

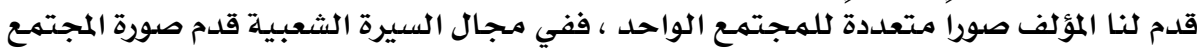

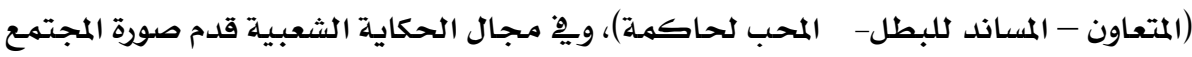

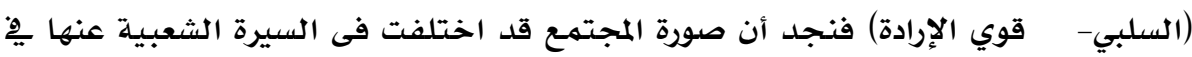

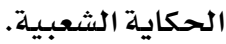

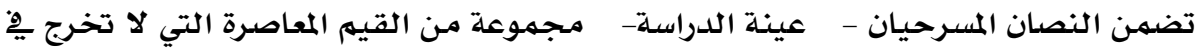
إطارها عن السلوكيات التربوية ؛وذلك بهدف ان تقدينه النهان إلى إلى عالم الطفل. 


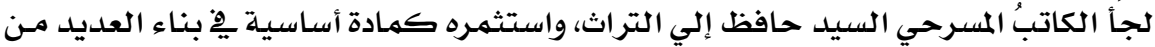

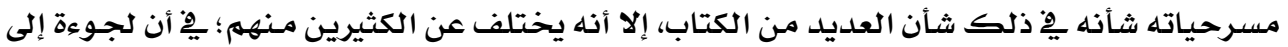

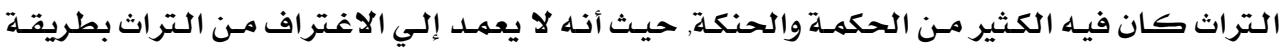

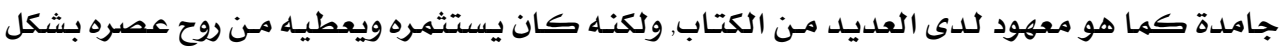

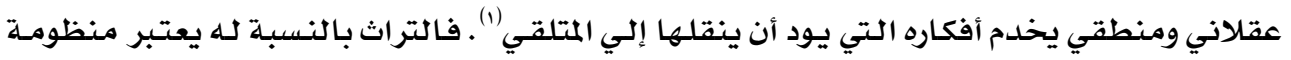

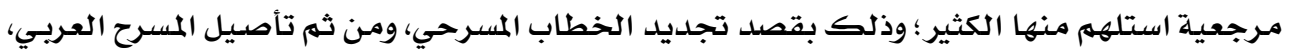

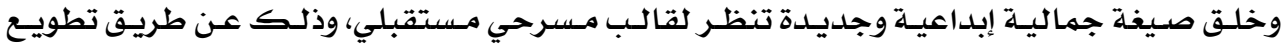
التراث ،وكذا تربية الذوق الفني لدي الدئل المتلقي. فالسيد حافظ اعتاد فِ العديد من مسرحياته المخصصة لعالم الأطفال أن يتعرض للتراث

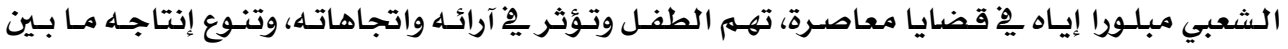

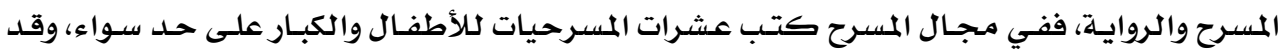

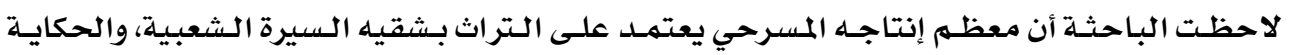

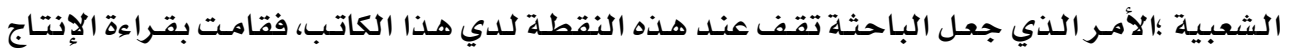

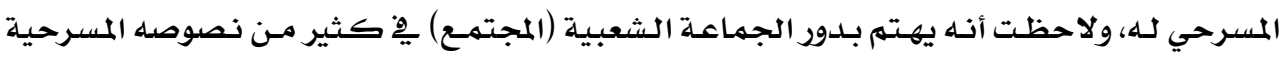

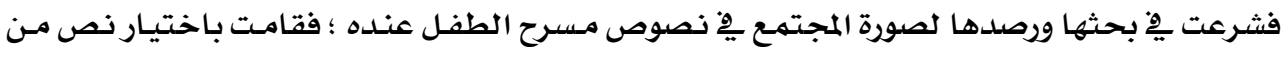

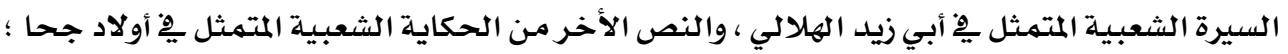

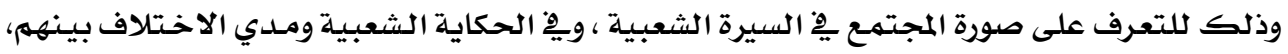

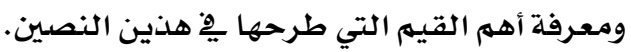

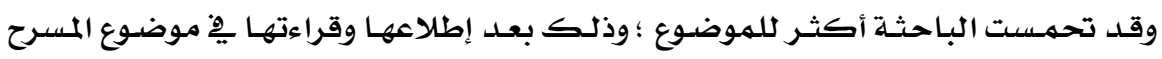

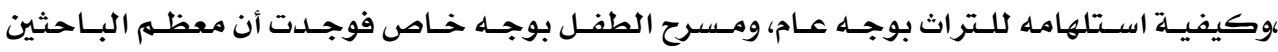

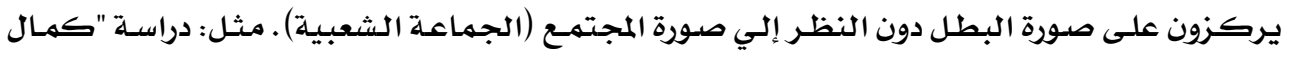

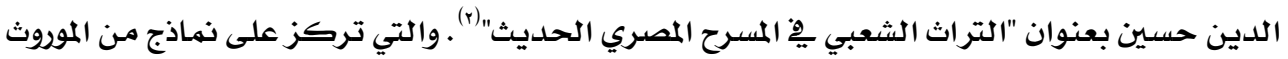

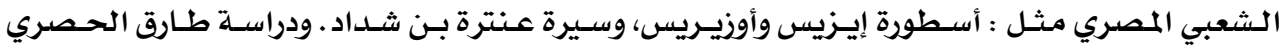

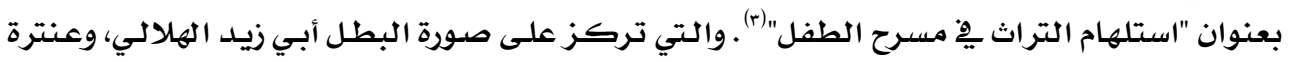

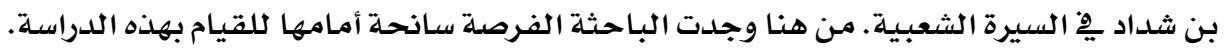

التراث هو القيمة الثابتة عند كل الأممه التي تبني منـه حاضـرها ومستقبلها ؛ لـذلك ينهل

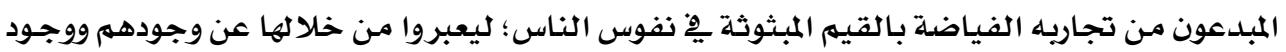

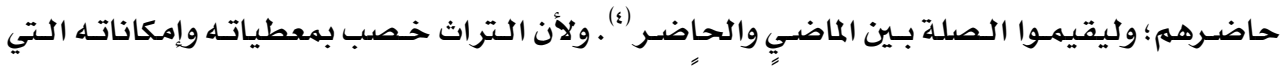

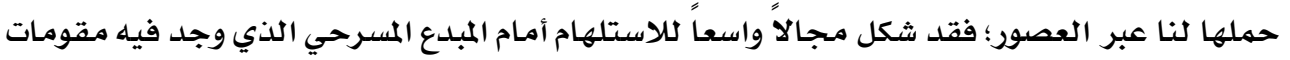


فكرية وإبداعية تهكنه من التعبير عن الهموم والقضايا التي تشغله، فالعودة إلي التراث ينبغي أن تكون

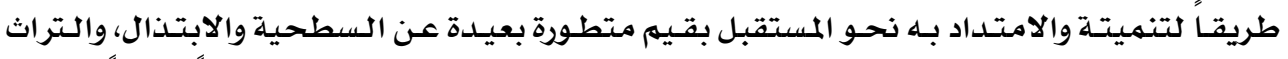

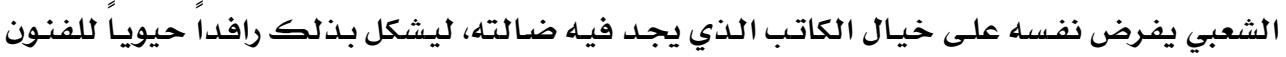

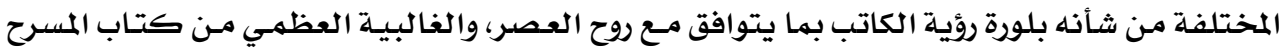

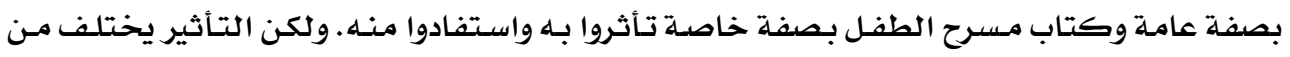

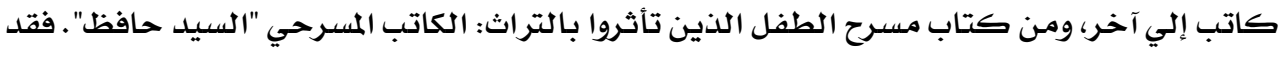

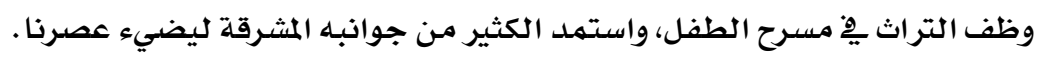

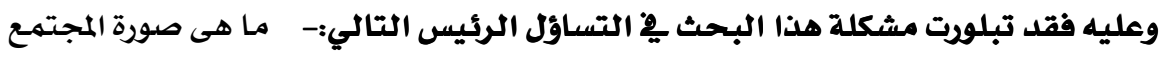

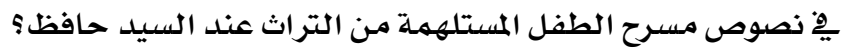

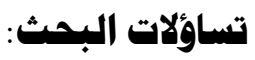

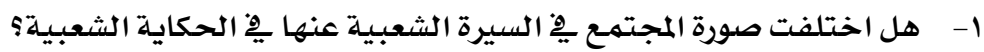

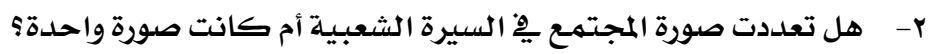

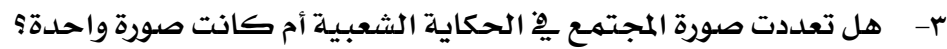

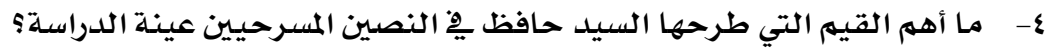

\section{أهميـه البحث:}

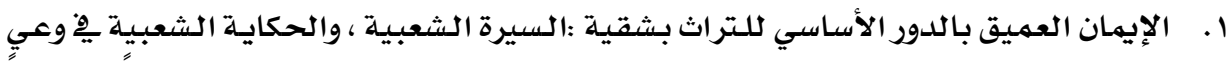

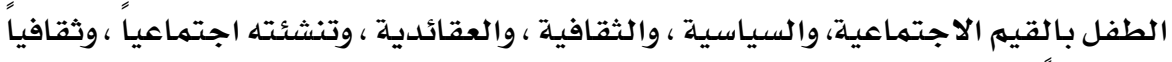

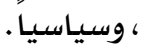

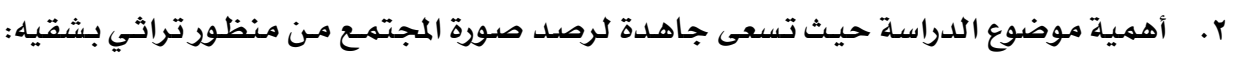

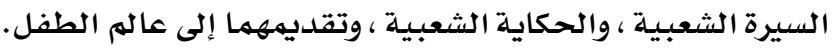
r. إثبات أن التراث هو منبـع لا ينضب من الإبـاع لكل كتًاب مسرح الطفل.

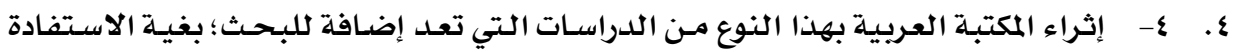
منها يِّ مجال البحث العلهي. 


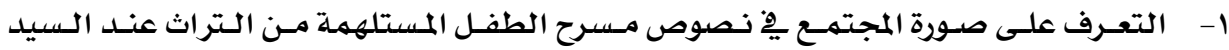

حافظ.

r- معرفة أهم القيم التي طرحها السيد حافظ يف النصين المسرحيين عينة الدراسلة.

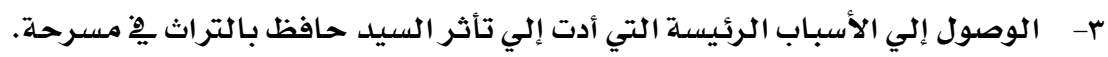

هدود البحث:

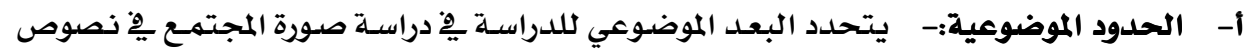
مسرح الطفل المستلهمة من التراث عند السيد حافظ.

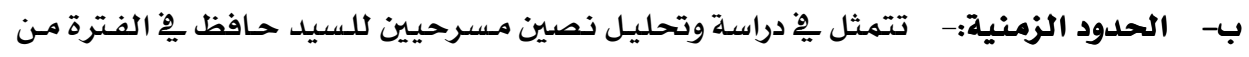
.

\section{الدراسات السابقة:}

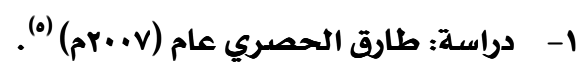

\section{بعنوان. "استلهام التراث مِّ مسرح الطفل".}

تناول الباحثُ يِّ هذه الدراسـة السيرة الشعبية ، وضرورة تقديمها للطفل ، ثم تعرض لأعمال

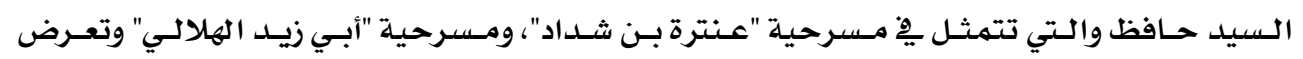

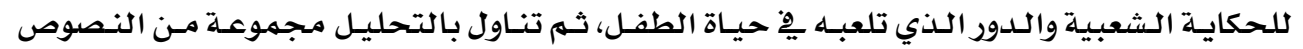

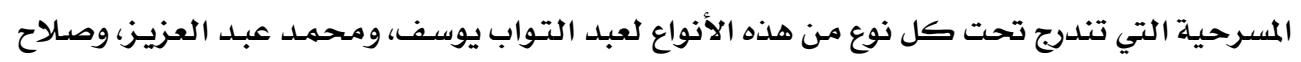

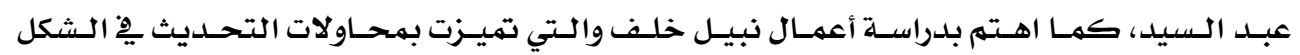

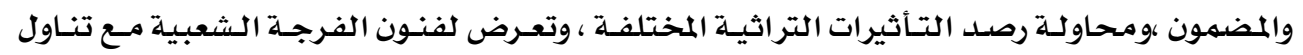

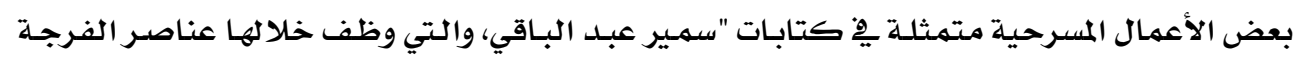

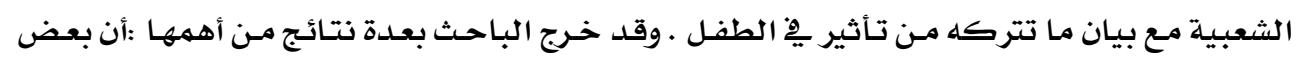

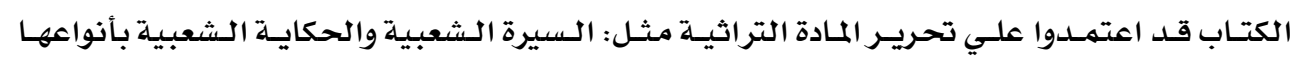

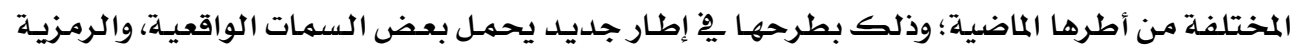

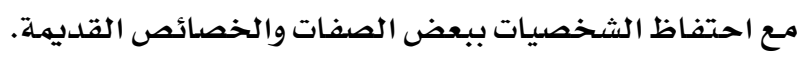

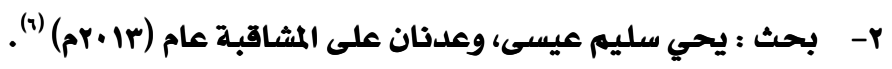
بعنوان."آليات توظيف التراث يِ النص المسرحي الإماراتي وكيفياته". تناول هذا البحث آليات توظيف التراث ِِّ النص المسرحي الإمـاراتي مـن خـلال دراسـة نهـاذج

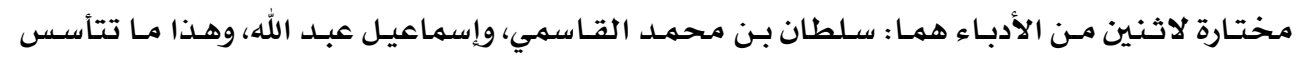

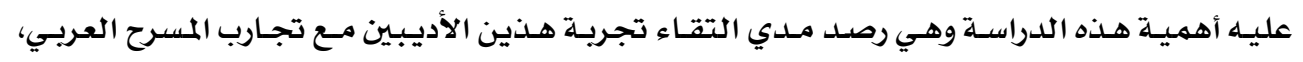

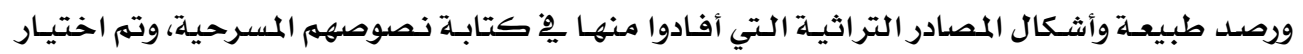




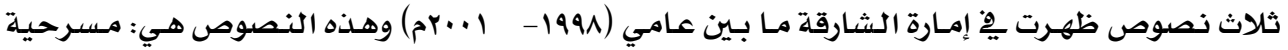

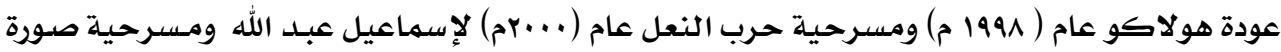

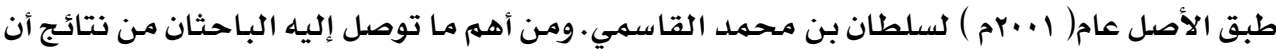

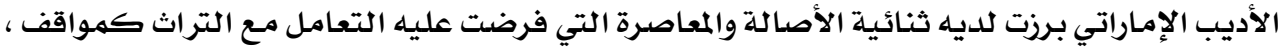
وحركة مستمرة من شأنها أن ترسيخ القيهم الإنسانية المثلي.

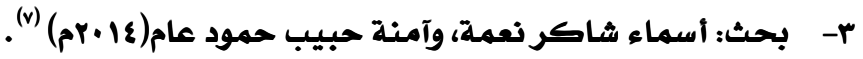
بعنوان. "الحكاية الشعبية ِِ نصوص مسرح الطفل".

استعرضت الباحثتان الحكاية الشعبية يِّ نصوص مسرح الطفل ، ومدي نجاح كتاب درامـا

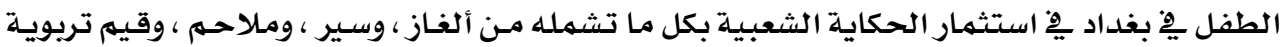

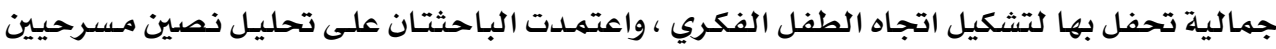

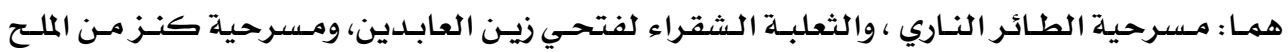

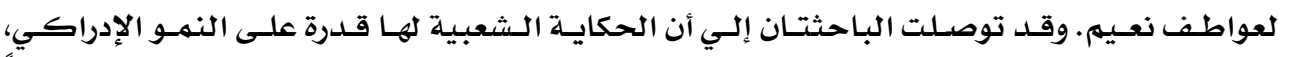

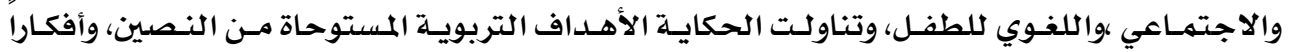

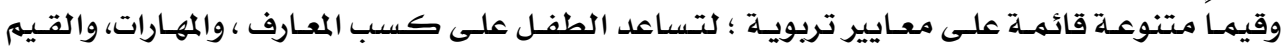

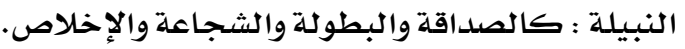

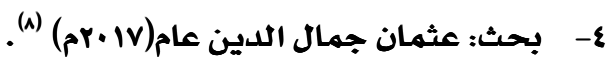

\section{بعنوان: "توظيف القصص والحكايات الشعبية ـِ مسرح الطفل بالسودان"}

هدفت هذه الدراسة إلي التعرف على مكونات الحكاية الشعبية ، وإمكانية توظيفها ِِِ مسرح

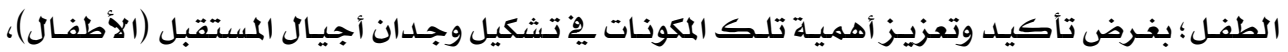

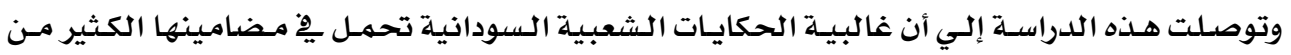

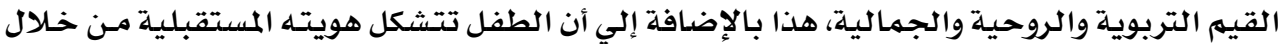

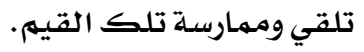

\section{التعليق على الدراسات السابقة:}

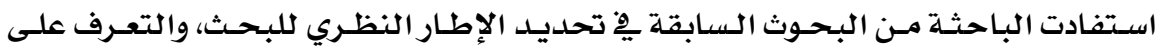

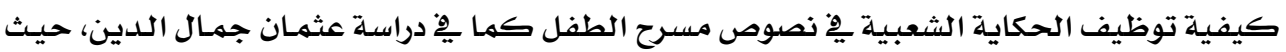

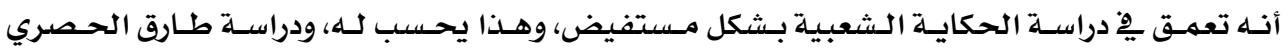

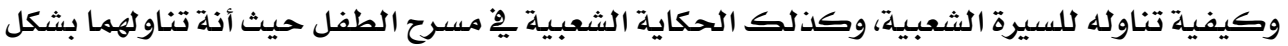

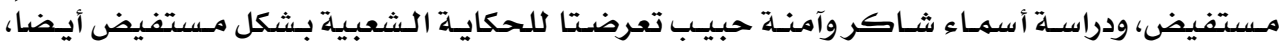

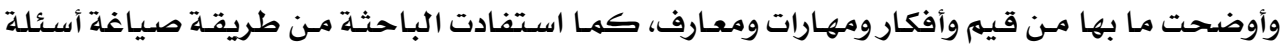

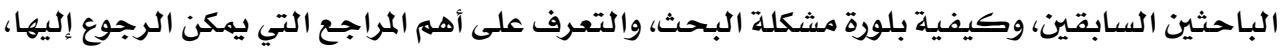
وكذلك التعرف على كيفية تحليل النصوص المسرحية. 
هذا البحث من البحـوث الوصفية يِّح تحليل المضمون، "وتحليل المضمون يستهدف الوصف

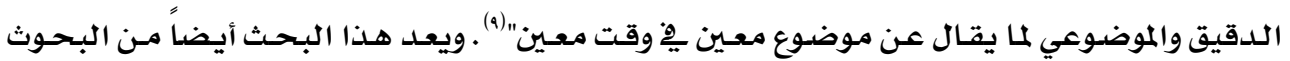

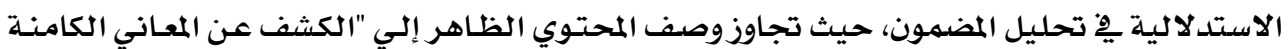
وقراءة ما بين السطور. (1.).

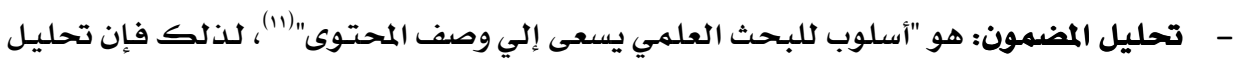

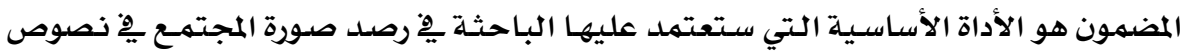

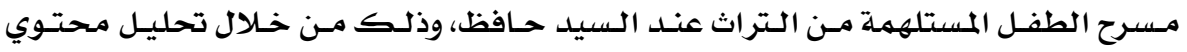
النصين المسرحيين عينة الدراسلة.

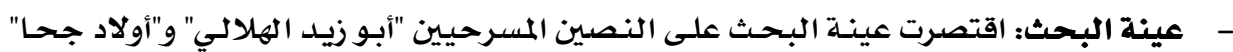
للكاتب المسرحي السيد حافظ.

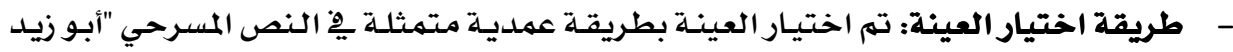

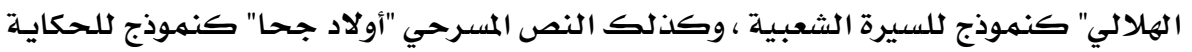

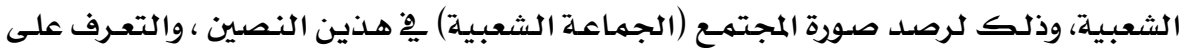

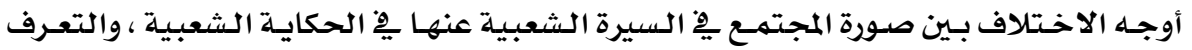
على بعض القيه الموجودة ِِّ هذين النصين (عينة الدراسة). همطاحمات البمث: اـ المجتمع (الجماعة الشعبية):

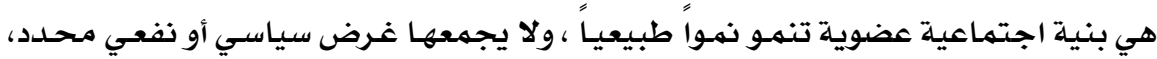

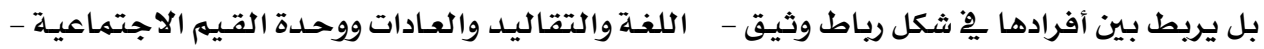

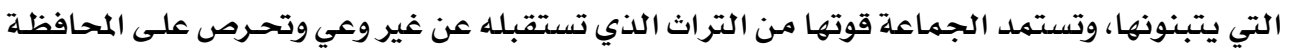

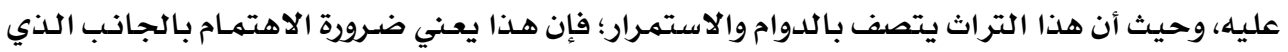

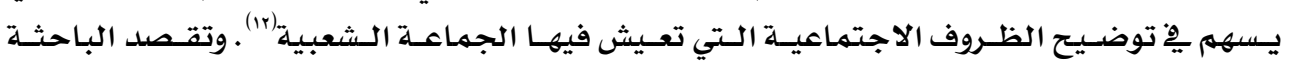

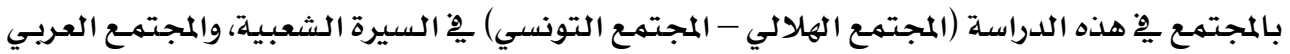

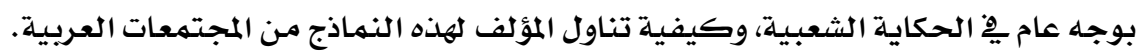

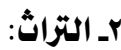
لغوياً الكلمة مشتقة من الفعل ورث، ومـرتبطة دلالياً بالإرث والميراث والتركة والحسب، ومـا

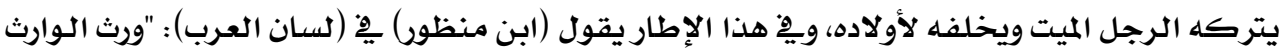

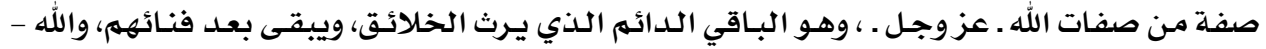

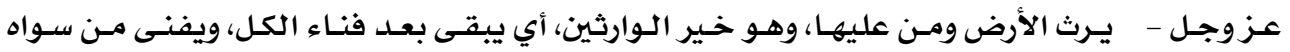

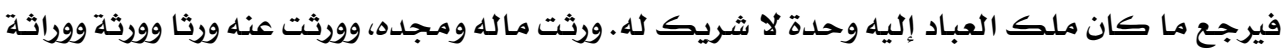




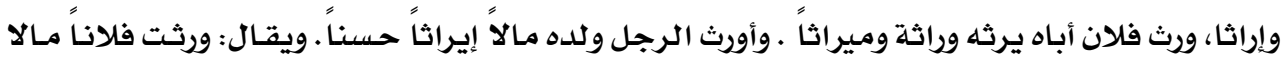

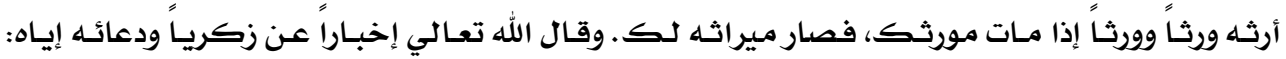

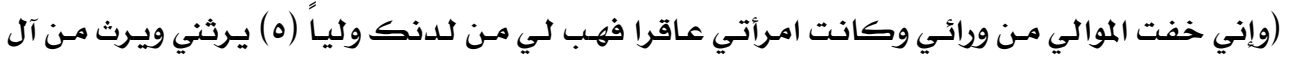

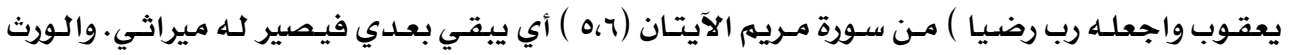

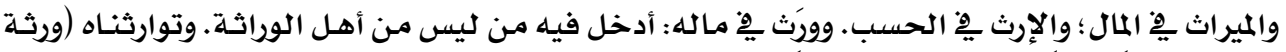

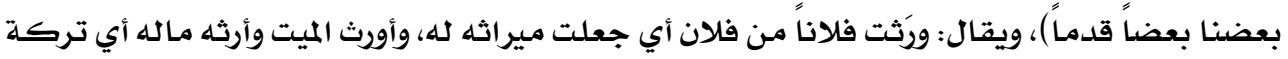

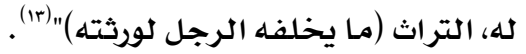

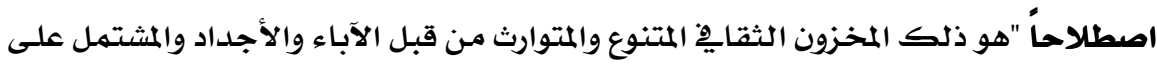

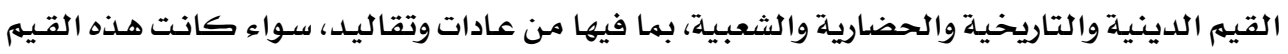

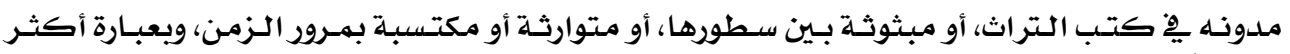

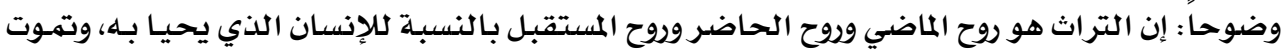

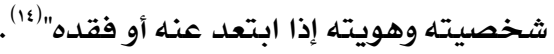
التراث. "هو تجارب السلف المنعكسة يِّا الآثار التي تركوهـا ِِِ المتاحف أو المقابر، أو المنشآت

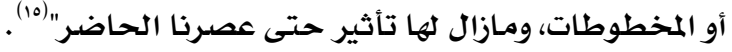

السيد حافظ:

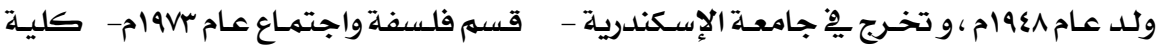

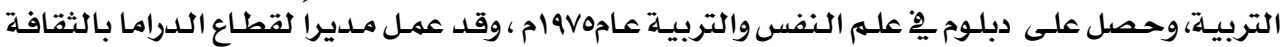

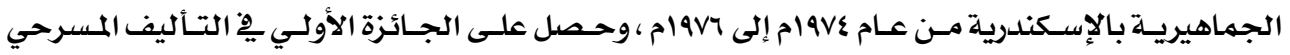

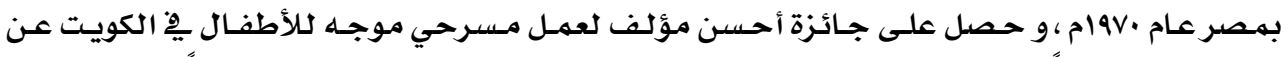

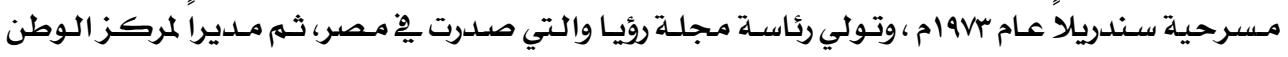

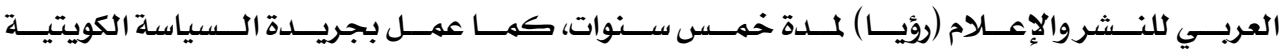
كمدة V سنوات. صدر للمؤلف مطبوعات مسرحية للأطفال منها : سندس، وعلى بابـا، وعنترة بـن شـداد، وأبو

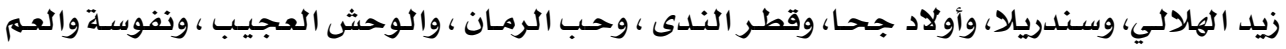
كمال، حمدان ومشمشية (17). أسباب توظيف التراث في المسرح العربي:

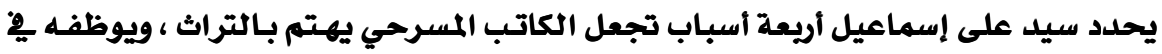
إبداعه وهي:ا- الفخر بمآثر العرب: وهذا السبب غالباً ما يأتي عندما يشعر الكاتب بعدم تقدم الأمة العربية

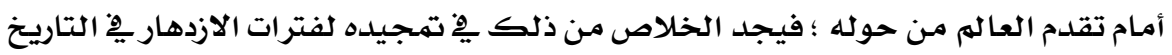
العربي والإسلامي. 
r- الوقوف أمـام المستعمر: لقـد حـاول الاستعمار الأجـنبي أن يطمس هويـة الشخصية العربيـة

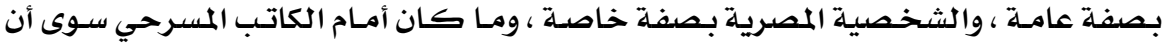
يتمسك بشخصيته العربية أمام المستعمر.

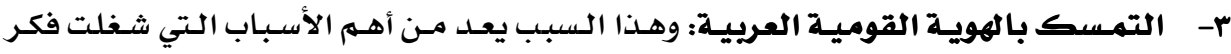

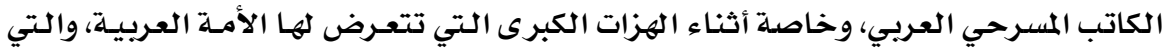

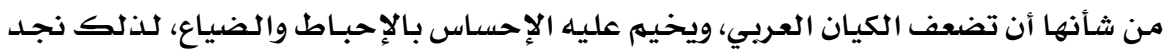

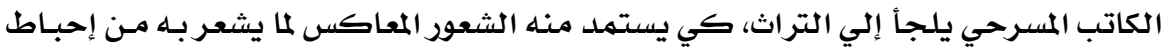

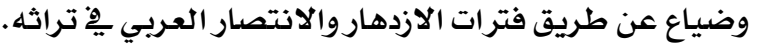
ع- محاولة التأصيل للمسرح العريب: لقد أراد الكاتب المسرحي العربي أن يحطم قيـود المسرح

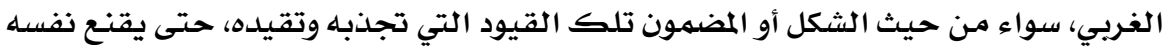

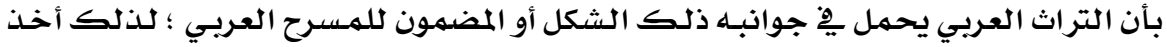

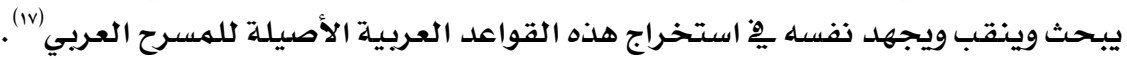
وقد قسمت الباحثة هِِ هـا البحث الـتراث إلي: (سيرة شعبية، وحكايـة شعبية)، وسـيتم تناولهم على النحو التالي:

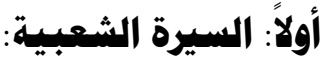
هي أحد فنون التراث الشعبي الـذي هـو ِِّواقع أمـره الحصيلة الكاملـة لثقافـة الشعب على

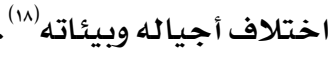
والسيرة لغة هي الطريقة والهيئـة "يقـال سـار الكوالي يْ (رعيتـه سـيرة) الطريقة ؛ويقال سـار

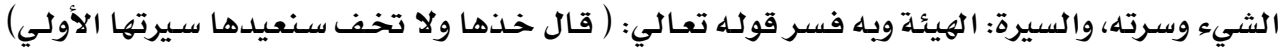

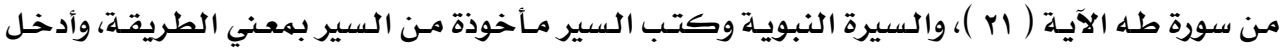

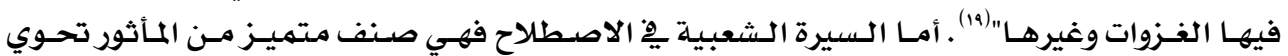

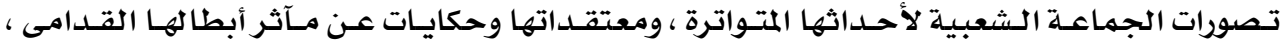
وقصصها المضافة القائمة على أساس من أخبار عصورها السـالفة التي تناقلتها عبر الأجيال (r.r.

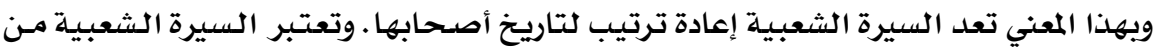

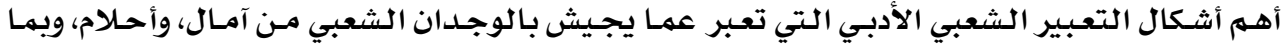

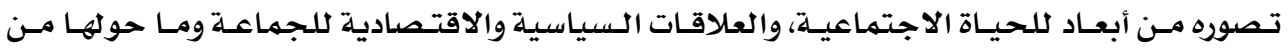

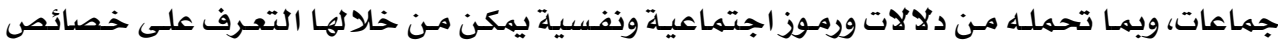

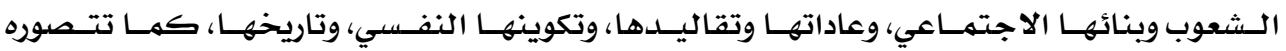
وتنشده (r)

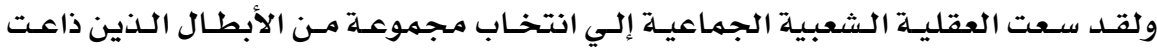

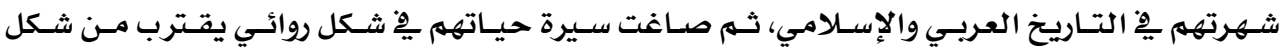




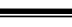

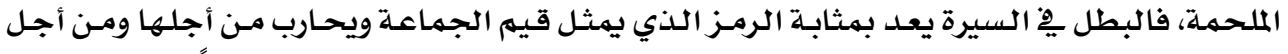

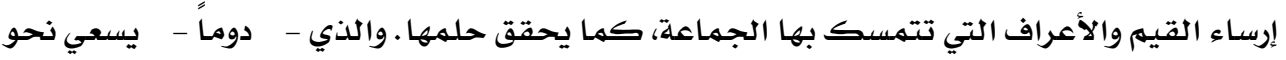

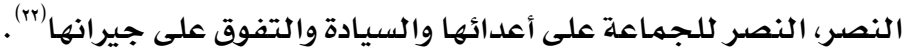

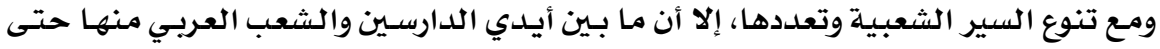

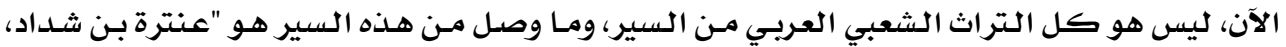

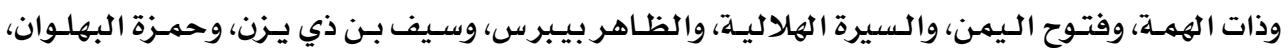

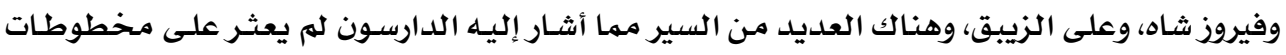
لها

والأصل ِِّ تداول السيرة كان ولا يزال شفهياً، فقد روتها جموع الشعب العربي وظلت تتغني

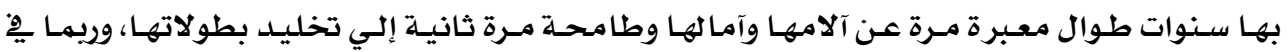

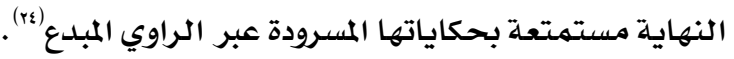

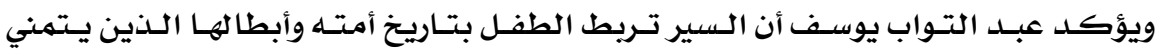

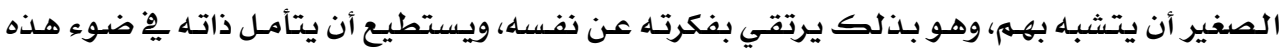

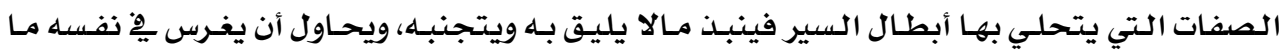

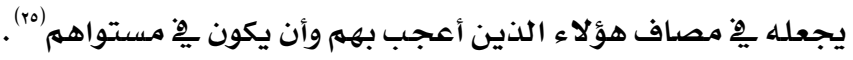
خصائص السيرة الشعبية:

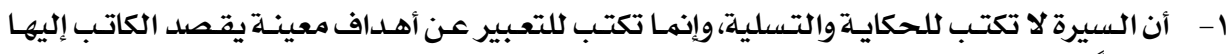

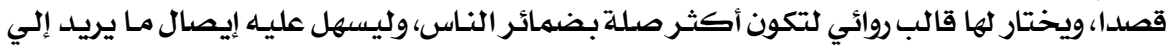

قلوبهم.

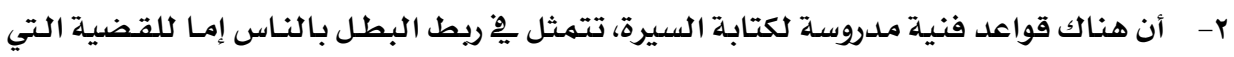

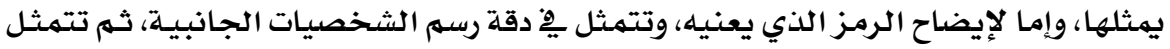

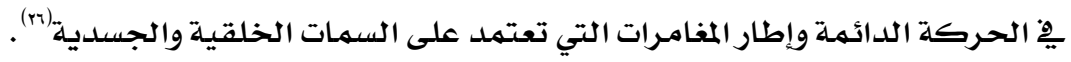

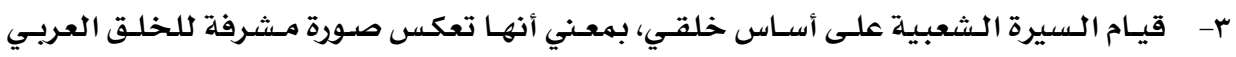

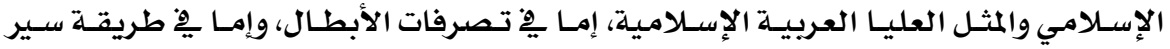

الأحداث.

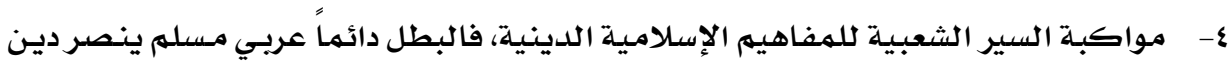

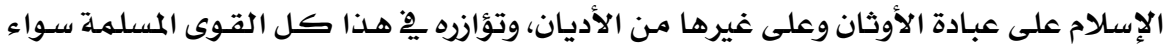

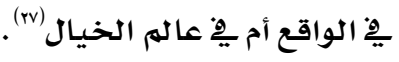
ه- من حيث الشكل هي قصلة متكاملة لها بداية ووسط ونهاية وشخصيات وحبكة وعقدة وما إلي

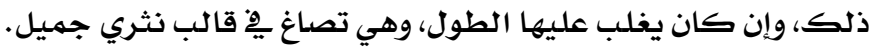
צ- تولـد السيرة الشعبية مـن رحسم الواقـع الشعبي، التـاريخي والاجتمـاعي والفكـري، والثقـايِ 
والحضاري، وهي تجسده وتعبر عنـه، عن طريق تحويل الواقع التاريخي إلي واقع أدبي شعبي،

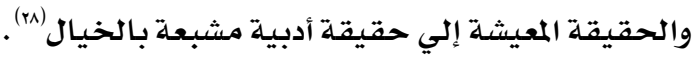

\section{مراحل السيرة الشعبية:}

\section{لقد مرت السيرة الشعبية بمرحلتين:}

ا- مرحلة التجميع: التي عكف فيها مؤلفون متخصصون ورواة معروفون على تجميع ما لديهم،

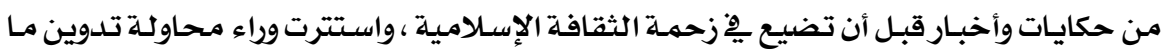

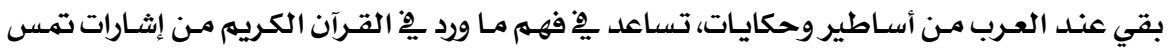

$$
\text { تاريخ العرب وشعوب الجزيرة العربية. }
$$

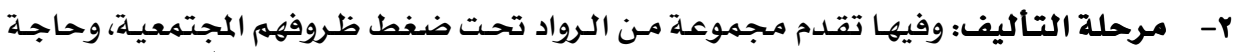

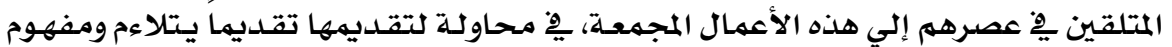
العصر، ويساير الحاجات الفنية للحياة من حولهم (ra) .

\section{ثانياً: الهكاية الشعبية:}

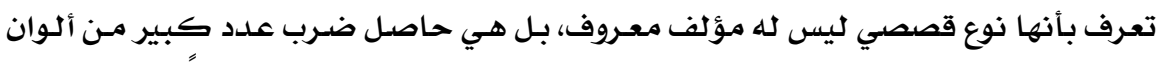

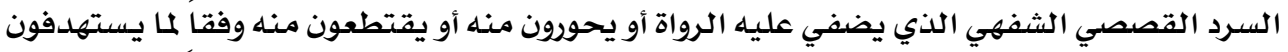

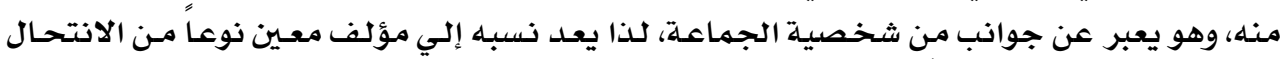
ولكن يظل هِ طبيعته شعبياً (r.).

وتعرفها نبيلة إبراهيم بأنها: "الخبر الذي يتصل بحدث قديه ينتقل عن طريق الروايـة الشفوية

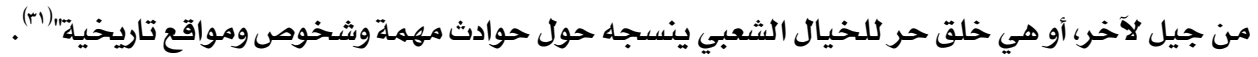

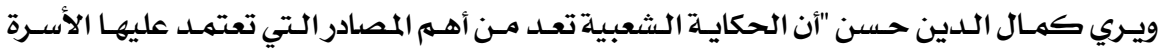

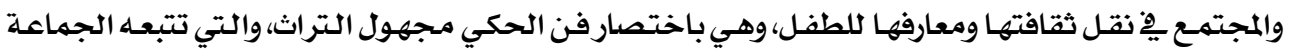

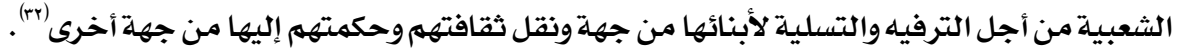

فالحكايـة الشعبية تعتمهد على أنسنـة الحيوانـات، والنباتـات، والجمـادات، كهما أنها مفعمهـة

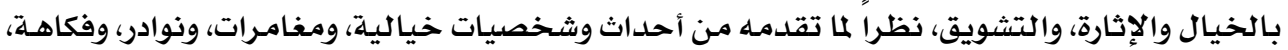

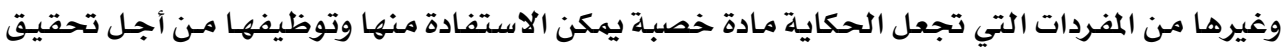

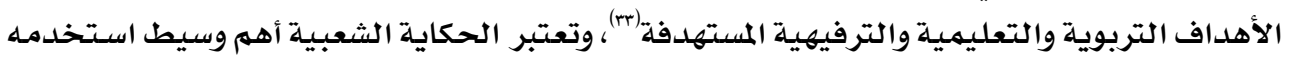

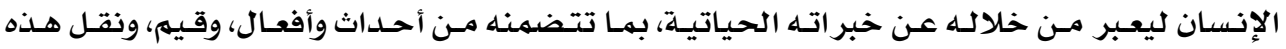

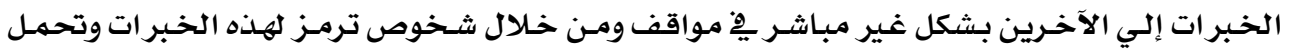

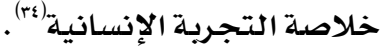

ويؤكد صفوت كمال أن الحكاية الشعبية المصدر الأساسي لكل المرويات الشفهية وأكثرها

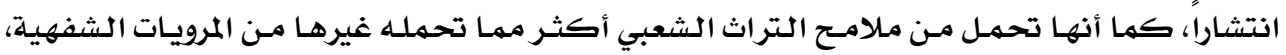

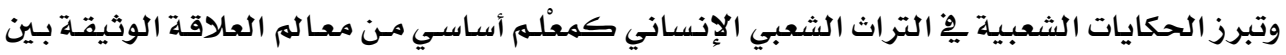




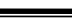

التراث الشعبي وأدب الأطفـال، باعتبـار أن الحكايـة الشعبية بطبيعتهـا الفنيـة والتاريخيـة هي العنصر

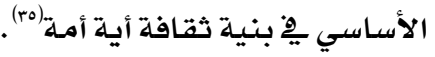

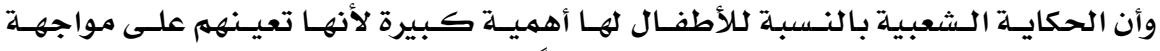

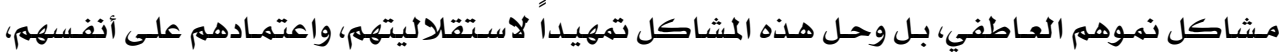

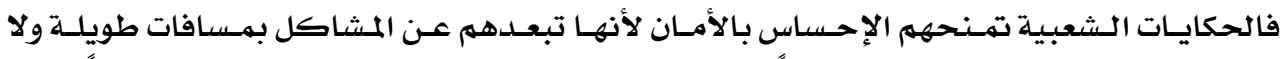

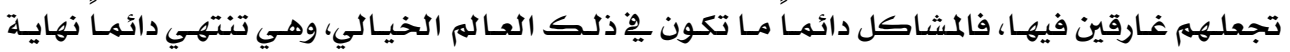

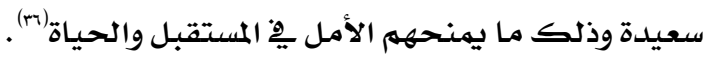

حيث أنها عبرت عن تطلعـات الإنسان وتـراث الشعوب ووجـدت طريقها إلى قصص الأطفـال

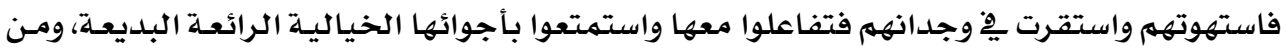

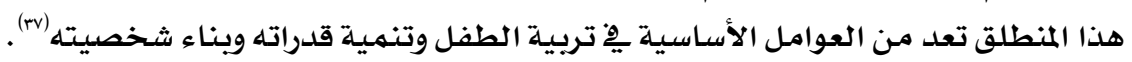
تصنيف الحكاية الشمبية:

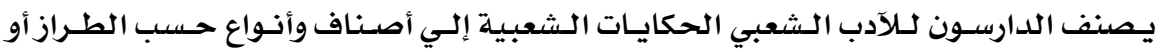

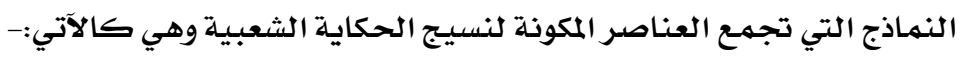
ا- - مكايات الحيوان:

وهي تعد من أقدم أشكال الحكايـات الشعبية حيث يقوم فيها الحيوان بالدور الرئيس، فقــ

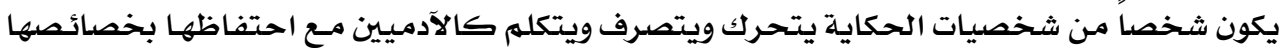

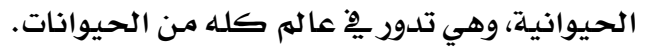

\section{r- حكايات الخوارق:}

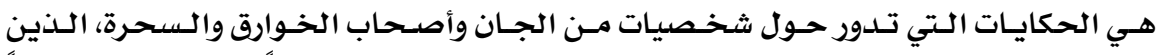

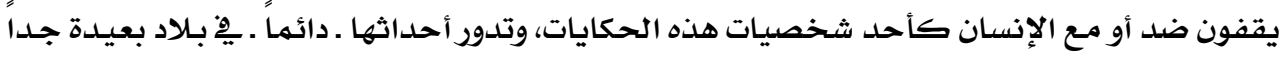

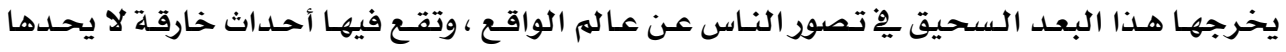

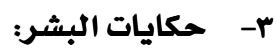

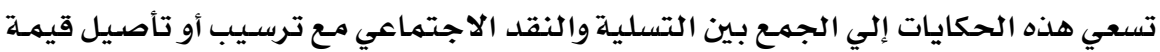

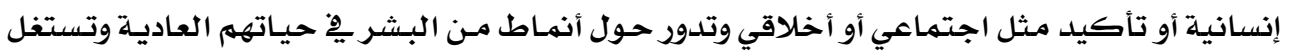

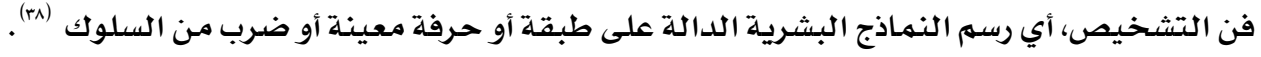
ومن أشهر نماذج هذه الحكايات "حكايات الشطار" وتدور حول اختبار قدرة البطل على القيام

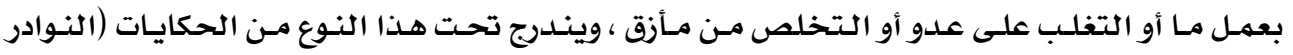

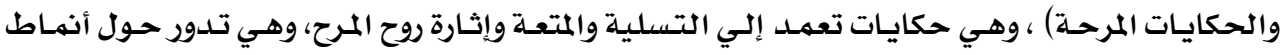

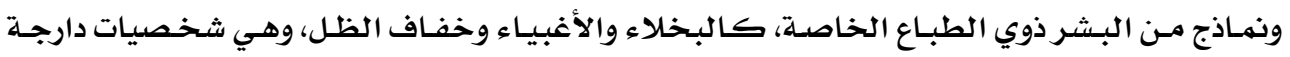


تواجه مشكلات عادية ملموسـة وتنتهي عادة إلي موقف أو نكتة مرحسة، والقصد منها النقـد الاجتمـاعي

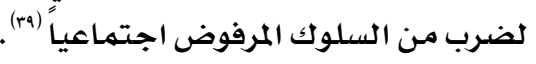

خصائص الحكاية الشعبية:

إن الحكايـات الشعبية على اختتلاف أنماطها وتعسدد أشـكا لها وانتشارها ِِِ البيئـات المحليـة

والعالمية إلا أن لها خصائص تميزها وهي:

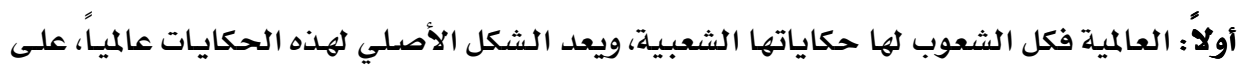

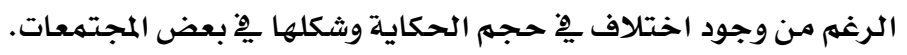

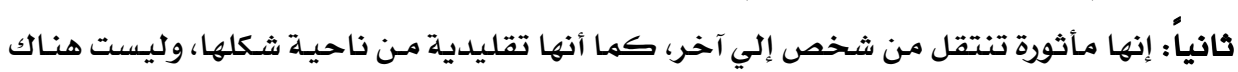

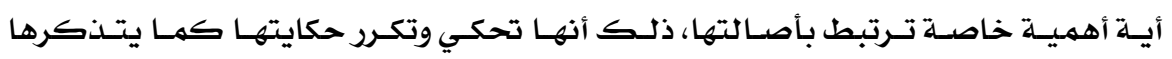

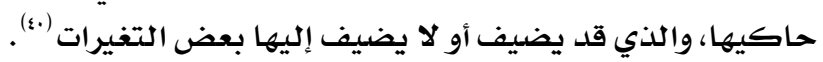

والآن سوف نتعرف علي صورة المجتمع ِِّ السيرة الشعبية، وِِّ الحكاية الشعبية.

أولاً: صورة المجتمع في السيرة الشعبية النص المسرحي (أبو زيلد الهلالي) نموذجاً:

يستند السيد حافظ يِّ هذه المسرحية إلي السيرة الهلالية، ويستوحي فكرته المحوريـة منهـا،

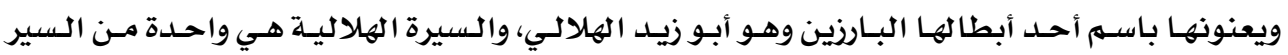

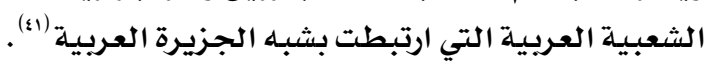

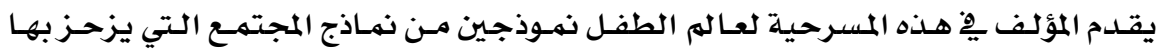

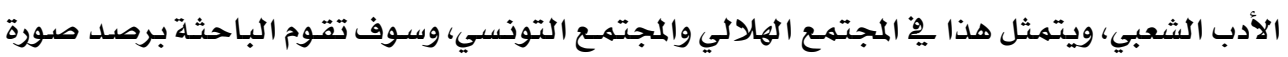

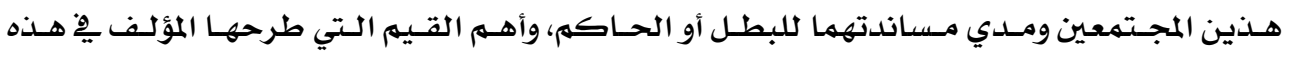

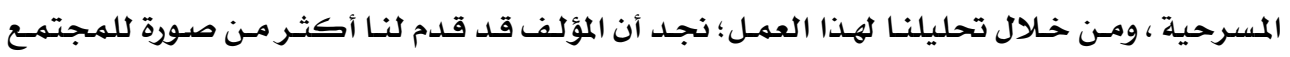

$$
\text { ا- الواحد، ويتضح ذلك من خلال الآتي: }
$$

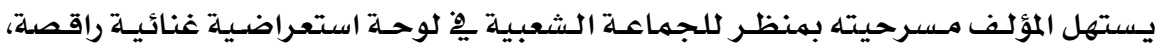
فنرى مجموعة من الناس وقد جلست على خشبة المسرح تغني أغنية جماعية بما معناه:

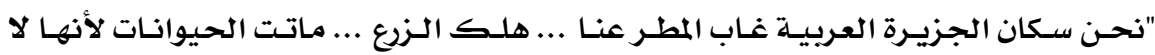

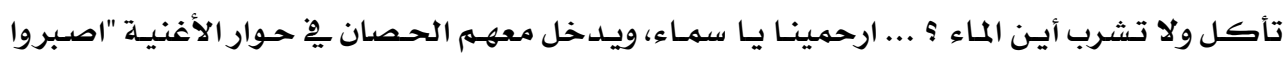

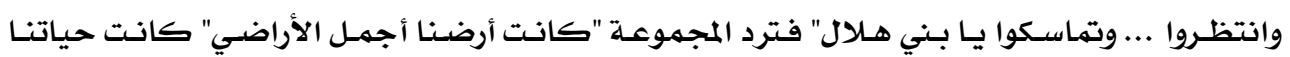
جميلة ... جف المطر جف المطر ...وخاف الناس ... وجاع الناس ... (rاع.).

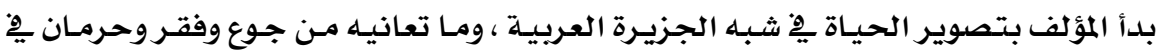

تلك الفترة، وقد جاء ذلك على لسـان مجتهمع شبـه الجزيرة العربيـة.

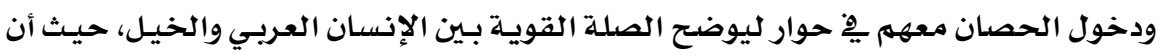

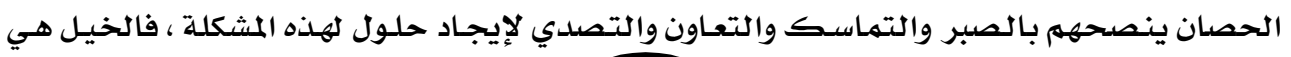




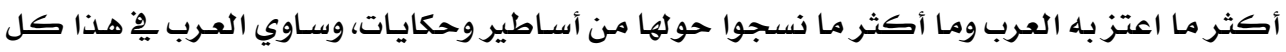

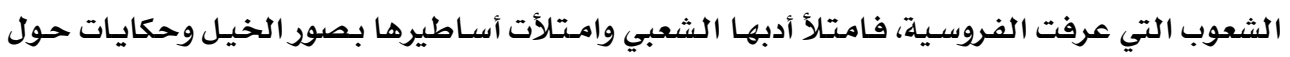

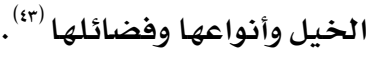

وأراد الكاتب أن يوضح للطفل حاكة العرب أنذاك، ويجعله يقارن بين النعهم التي أنعم الله بها

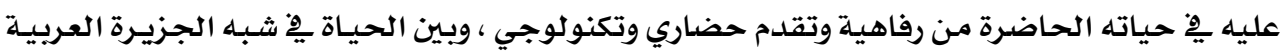

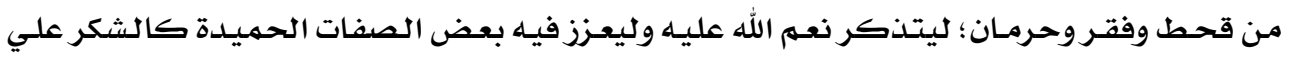

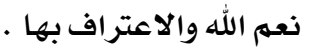

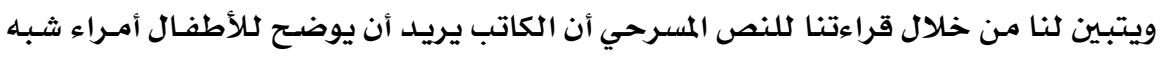

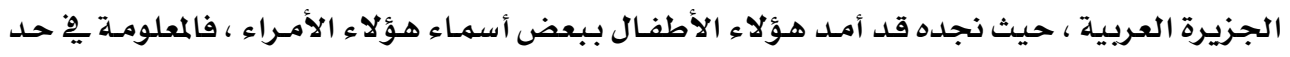

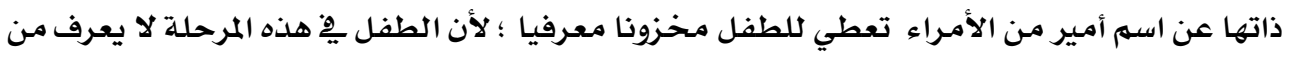

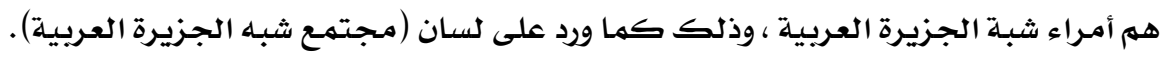

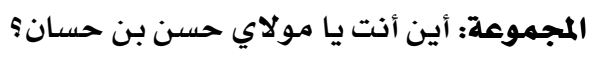

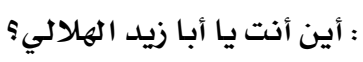

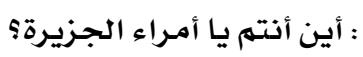

حسن: (يدخل يِّ دائرة الضوء) أنا الملك حسن أحكم قبائل بني هلال بالرأي والحكمة والفهم. المجموعة: مولانا الملك حسن ... عاش ... عاش ... نحن جوعي (\&).

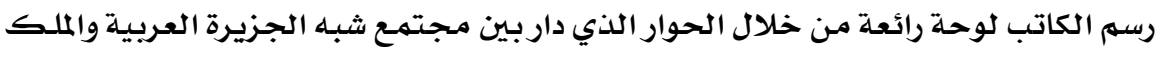

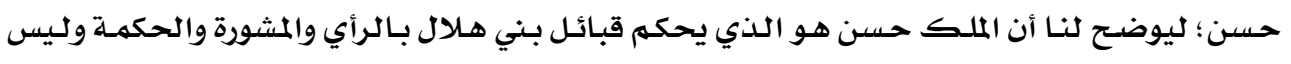

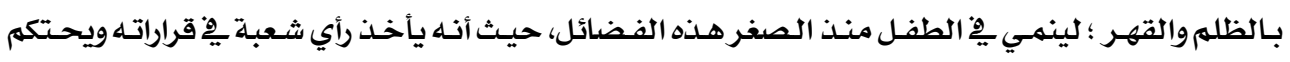

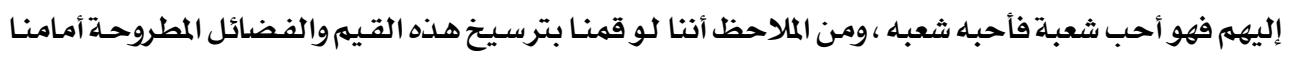

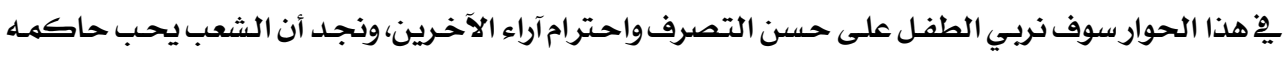

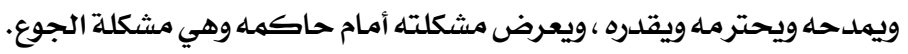
حسن: كفوا عن الكلام الآن .... سنعقد اجتهماعاً الآن. المجموعة: عاث الملك حسن بن حسان. حسن: أين الأمير دياب بن غانم ... احضروه الآن. دياب: (يدخل) أنا الأمير دياب بن غانم ... (يرتدي ثياب الفروسية ويحمل سيفه بين يديه) يا ملك البلاد. المجموعة: هذا الأمير دياب بن غانم.

$$
\text { حسن: أين أبو زيد؟ }
$$




$$
\text { (يدخل أبو زيد على المسرح وقد ركب الحصان..) (هو؛ }
$$

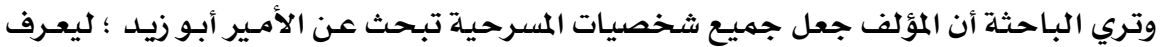

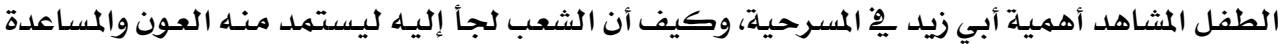

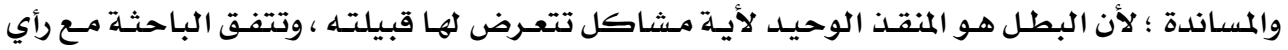

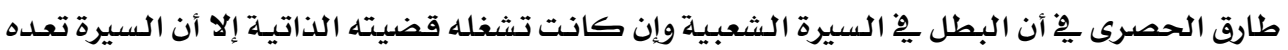

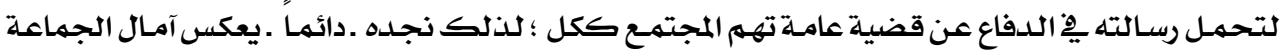

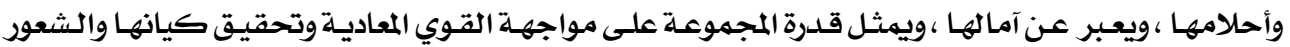

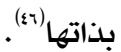

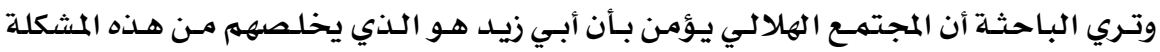

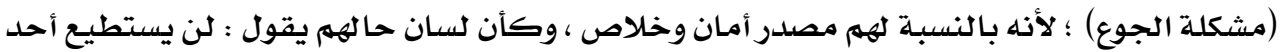

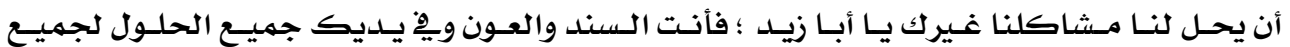
مشاكلنا.

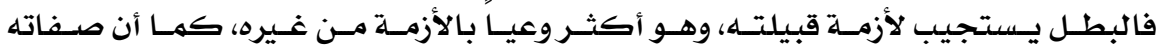

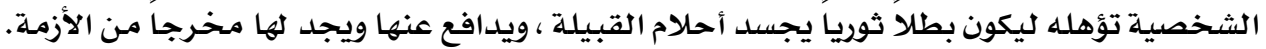
ويطالعنا موقف آخر للمجتمـع الهلالي ، فقد التف حول الملك حسن بن حسان لمعرفة أهـم

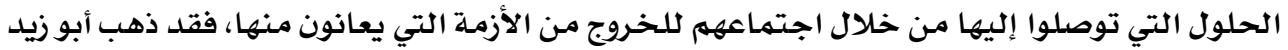

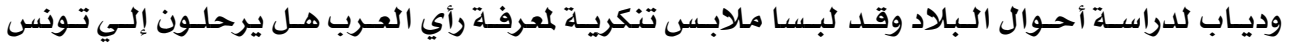

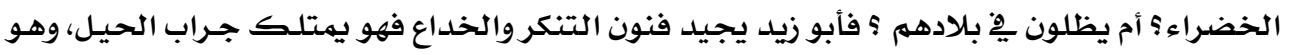

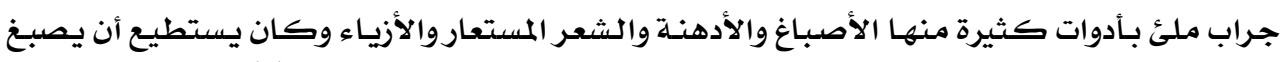

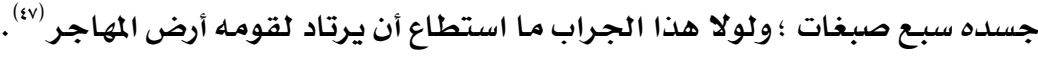
حسن: نعم أيها الناس لقد ذهب الأمير أبو زيد لدراسة أحوال البلاد والعباد. المجموعة: يا ملك العريان.

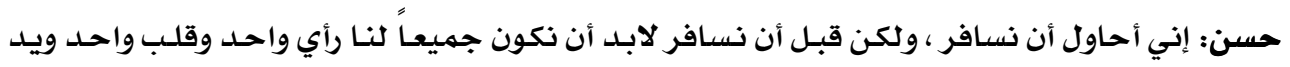

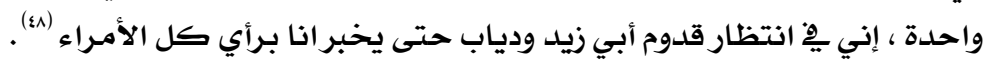

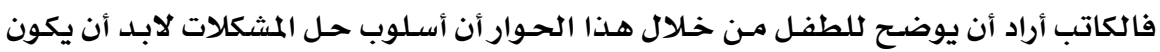

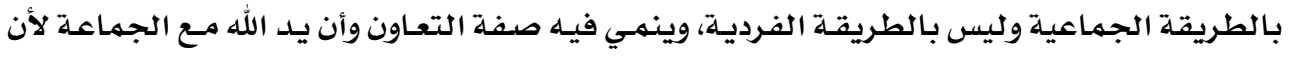

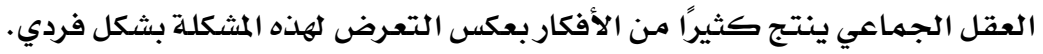

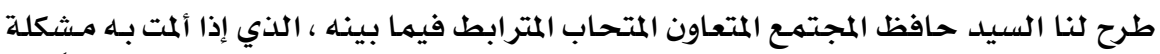

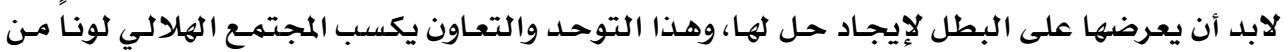

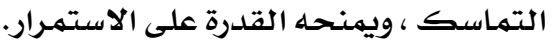




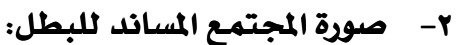

كان الأمراء متخوفين من عدم استجابة المجتمـح الهلالدي إلي الرحيل إلي تونس ، ولكن هذا

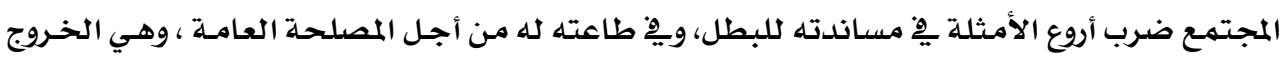

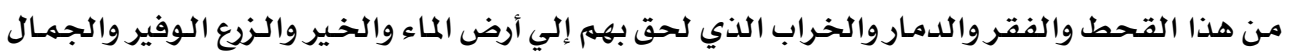

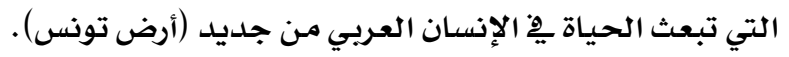
أبو زيلد: لقد جئنا لنسألك ولنعرف رأيك يـا أمير مفرج هل نرحل وتكون معناء

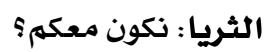
مفرج: دعيني أتحدث يا بنتي.

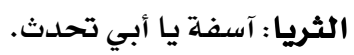
بهي: تحدث يا مفرج.

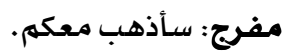

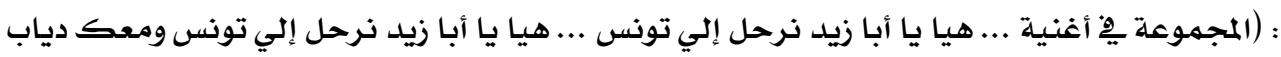

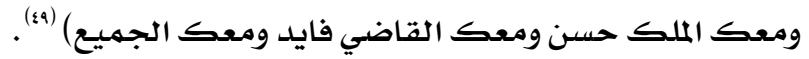

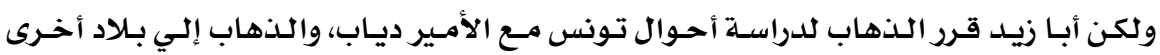

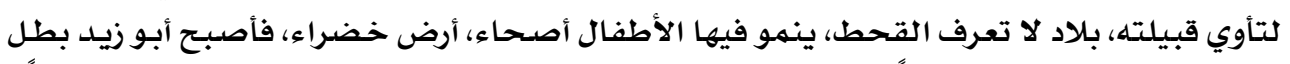

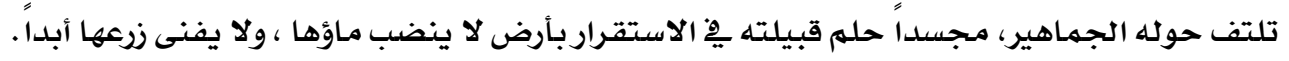

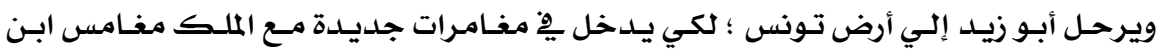

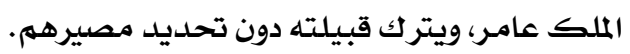
وينتقل بنا المؤلف إلي بالاد الأمير مغامس ابن الملك عامـر (أرض تونس) البلاد السعيدة...

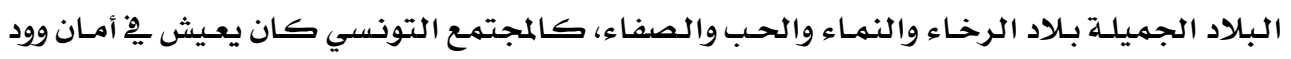

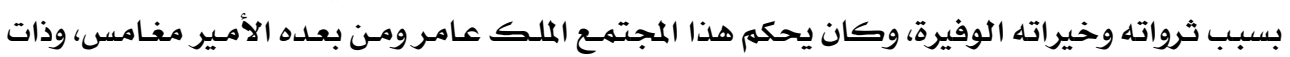

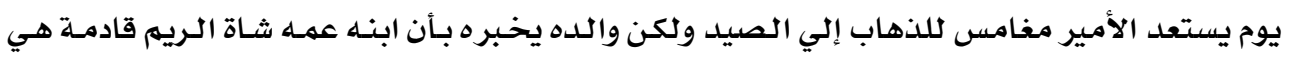

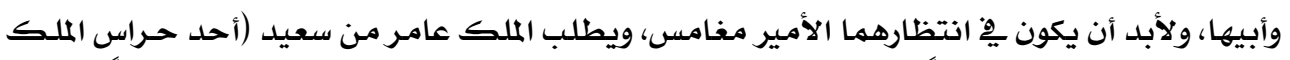

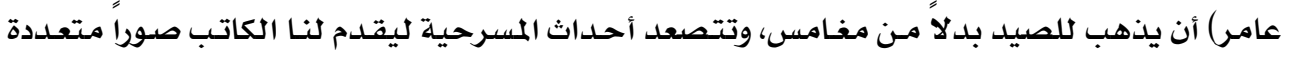

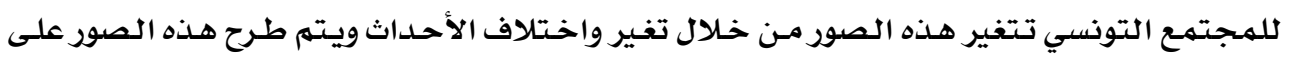
النحو التالي: 


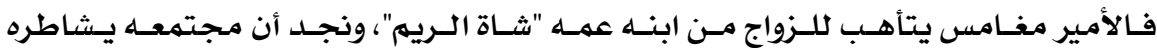
ويشاركه فرحته بهذه الزيجة السعيدة، وقد كشف الكاتب للطفل مـن خـلال هـذا الحـوار عن مـدي الصلة والترابـ والحسب الـذي جمـع بـين الشعب التونسسي والملـك عـامـروابنـه الأمسير مغـامس، هـذا الحسب جعـل الشعب قريبا من حاكمـه. لأن الحاكه هو الذي غرس فيـه هـذه الفضائل (الحب - الاحسترام- التقدير) منذ زمن بعيد ، ويف ظل هذه الفرحة الغامرة نجد أن الحارس سعيد يوزع الهدايا على الشعب بمناسبـة زواج

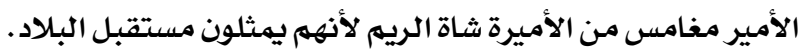
عامر: أتري أن نحدد ميعاد الزواج مـا رأيكم؟ مـا رأي العروس؟ شاة الريه: الرأي رأي الكبار. عامر: مبارك. المجموعـة: (تغــي) مـبروك زواج شـاة الـريهم مـن مغـامس الشـاب الرائع ع... الجميـل ... وشـاة الـريهم ...

$$
\text { الحلوة .... مثل الغنوه .... مثل الصبئاح). }
$$

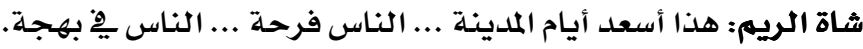
مغامس: هكذا أهلنا يفرحون بسرعة ويبكون بسرعة (.0. ولكن جو الحب والمودة لم يدم كثيراً بـين هذا المجتمع ، فقد حدث ماث ما يعوق إتهام هذا الزواج

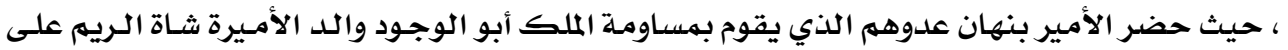
الـزواج مـنهـا ، ولكـن الملـك يـرفض فتقــوم بينههـا حـرب يـصـاب فيهـا الملـك عـامـرويهـوت الملـك أبـو الوجود، ويتطوع سعيد يِ المعركة وينتصر على بنهان ويطلب الملـك عـامر مـن سعيد أن يدير شـئون

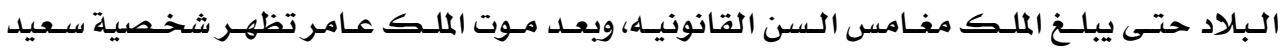

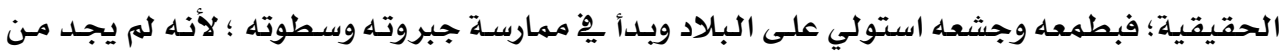
يواجهه بحزم وقوة فأمر بنفي الملك مغامس وأمـه إلي قصر بعيد. سعيد: اجمـع لي الأبطال والأمـراء ....والفرسـان ... عندي لهم كلام. الحارس: (يصفق) : (تدخل المجاميـع التي تهثل هذه المجموعات). سعيد: أيها العبيد ... أيها الفرسان... أيها الحراس. أيها الأبطال ... أيها الأبطال التجار ... من اليوم أنا حاكه البلاد. المجمموعة: (بهـرارة) نعم.

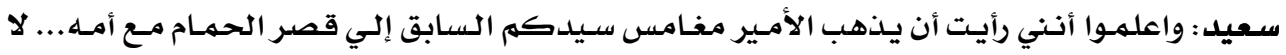
تعاملوه بالاحترام ولا بالانحناء ... ولا بأي شيء.

المجمموعة: (متذذمرة). 
مجلة بحوث التربية النوعية - علد

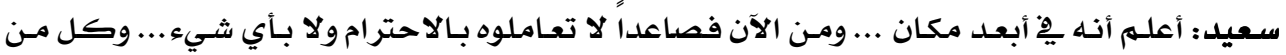

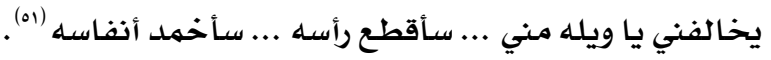

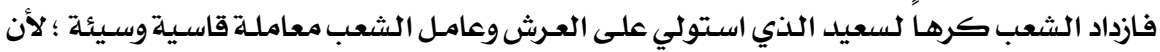

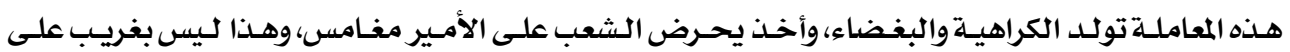

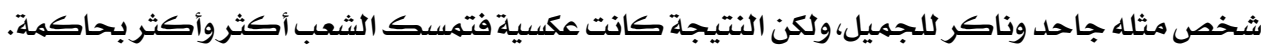

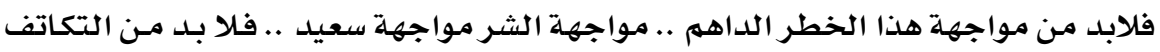
والتعاون من قبل الشعب .. لابد من تعاون الشعب مـع حاكهـة للقضاء على هـذا هـا الملعـون لكي يعيشوا مِّْ سعادة وسلام.

\section{ع- صورة المجتمع المساند لحاكمة:}

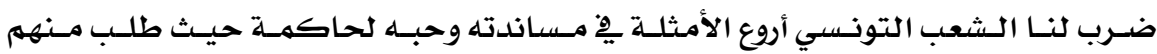

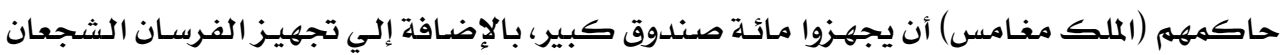

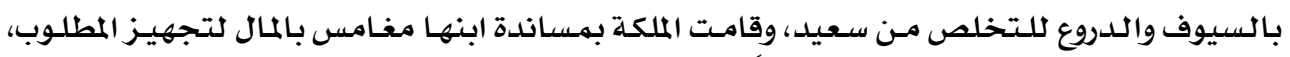

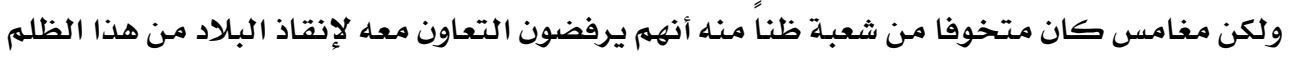

$$
\text { المتفشي فيها. }
$$

أم مغامس: جهز مـا طلب منك فوراً ... فعليك أن تستعد وتجهز الفرسان. مغامس: ماذا لو رفضوا وقالوا: إنهم ليسوا على استعداد.

أم مغامس: لن يرفضوا طلب ملكههم ... إنهم فرسانٍ شجعان وقفوا إِي جانبنـا ... أنا أسـاعدهم بالمال

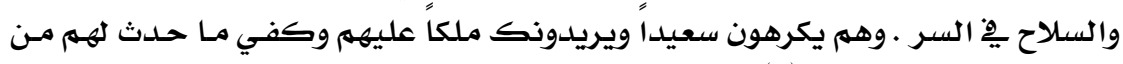

$$
\text { سعيد، يكفي ما جرى لهم (Or) }
$$

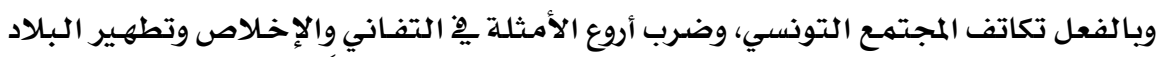

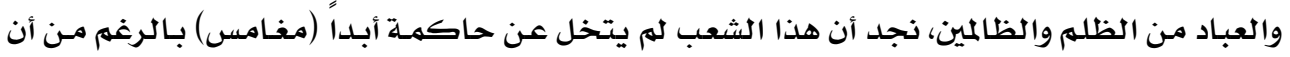

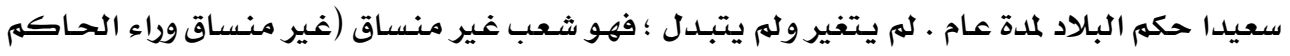

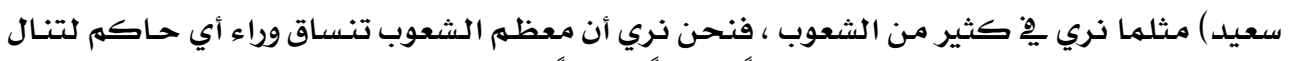

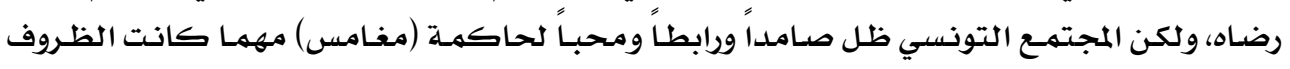

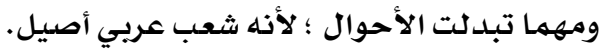

$$
\text { أم مغامس: مـاذا قالوا لكء }
$$

مغامس: قالوا لي أنت ملكنا ومولانا، مرنا نفدك بادل مالروح والدم. أم مغامس: عاشت الأمسة التي تحب قائدها. مغامس: يا أمي - لا أدري - هل حقاً سننتصر. أم مغامس: كلله بعون الله. 


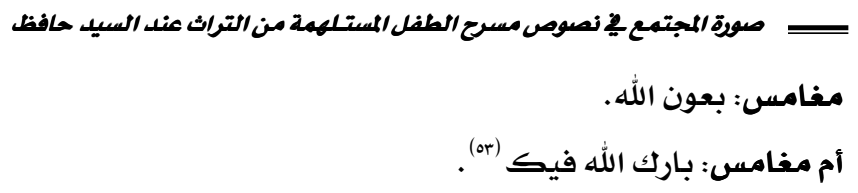

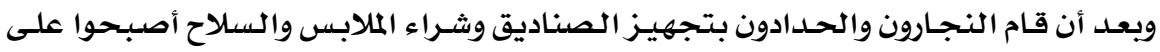

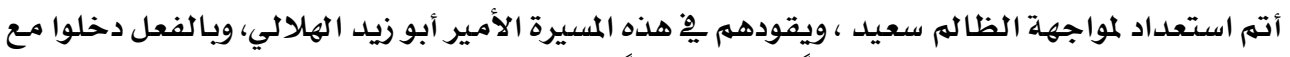

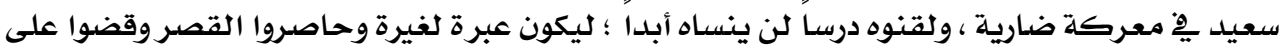

أم مغامس: يا فرسان الملك عامـر.

الفرسان: نعمى يا ملكة البلاد.

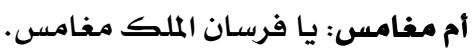

الفربسان: نعمم يا أم الفرسان.

أم مغامس: اليوم يومكم ... اسمعوا مـا قال أميركم.... وإني أدعوا لكمم مـن قلبي ... الله ينصركم الله ينصركم فتوحدوا وتماسكوا (os)

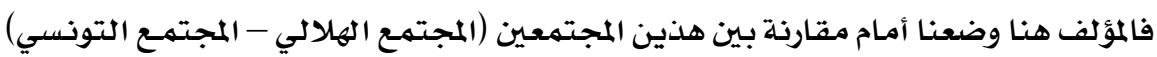

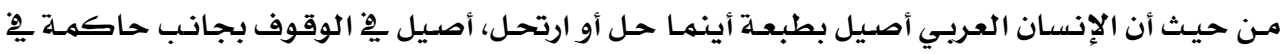

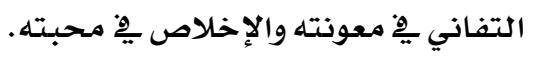

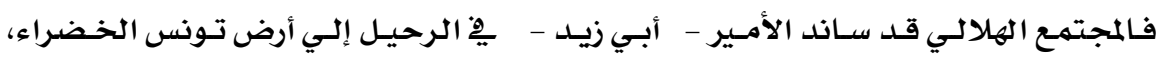

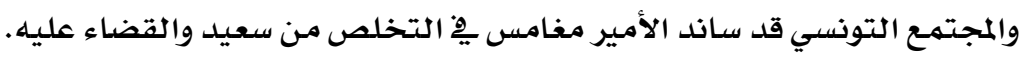
وقد ركز الكاتب على الربط بين الصورتين للمجتمعين ؛ لكي ينمي ِِّ الطفل صفة التعاون

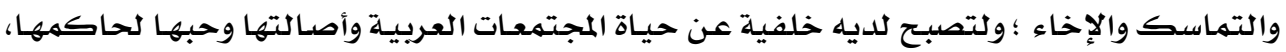

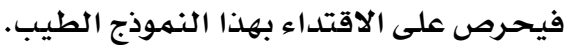
أهم القيم المرغوبة يِّ النص المسرحي أبو زيد الهلاكي:

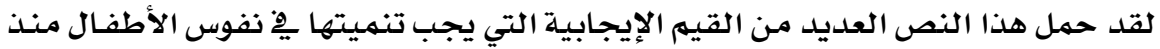

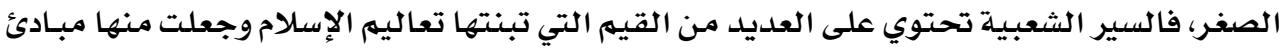

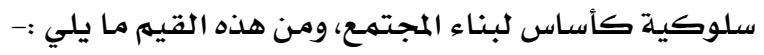

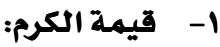

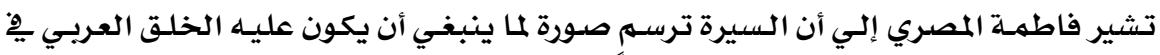

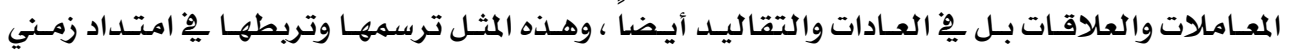
بالإسلام وظهوره (ماملات

ويتضح هذا السلوك ِِّ شخصيـة الأمير مفرح بن نصير عندما أتي إليـه ضيفان غريبـان ولا

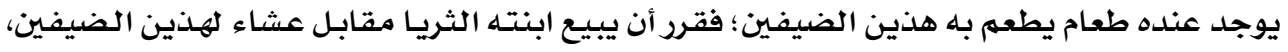


$\underline{\underline{2}}$

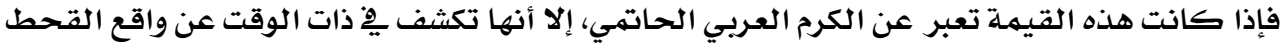

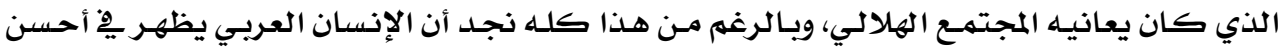
صورة أمام الغرياء.

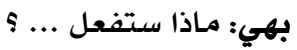

$$
\text { مفرج: هل لديك أي شيء نبيعـه؟ }
$$
بهي: لا يوجد أي شيء يباع إلا أنا وأنت والثريا. مفرج: الثريا (وكأن فكرة جاءت إليه).

بهي: الثريا (تؤكد الفكرة) اسمع يا مفرج ... بع ابنتك الثريا ....وبثمنها يأكل الضيوف. مفرج: (يحدث نفسـه) الثريا ابنتي الوحيدة ... ابنتي العزيزة ... كيف أبيعها ؟؟ وهـذان الضيفان إذا

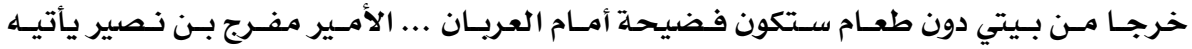

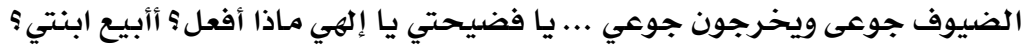

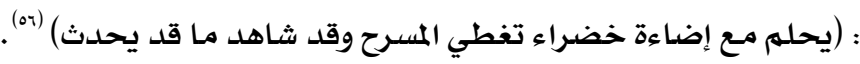

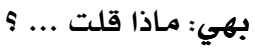
مفرج: هذا رأي صواب ... نعم الرأي ... قومي وأصلحي شـأنها وألبسيها أفضل الثياب حتى أبحث ِِ

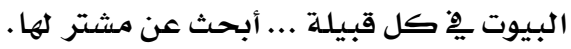

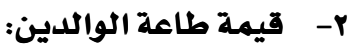

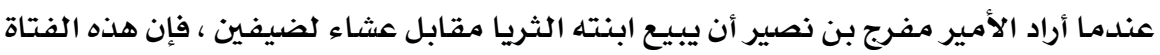

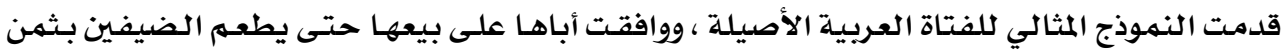
بيعها، لأن إكرام الضيف واجب. حسن: هل يعقل أن تبيع ابنتك؟؟ هل هذا معقول؟ مفرج: هذا كلام رجال العرب ...

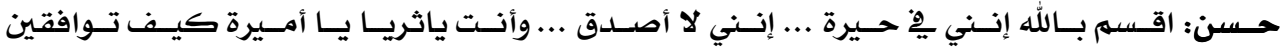
أباك .... الثريا: إنه أبي وطاعة الأب والأم واجبـة ..... r- الاعتماد على الله وحدة وعدم الاعتماد على السحرة:

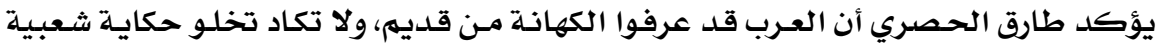

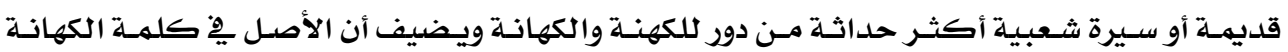

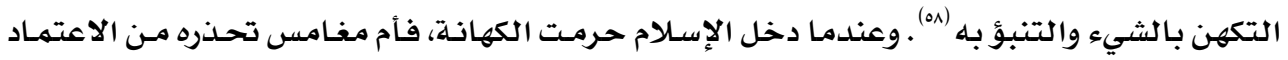

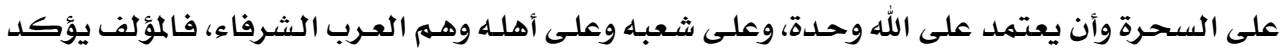

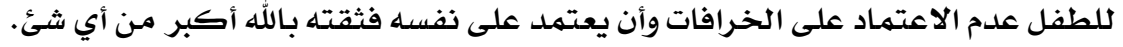



مغامس: (يدخل) أمي ... أمي... الأم: مغامس ... ماذا حدث. مغامس: جاء الفرج. الأم: من أين يجيء والأميرة شاة الريم ستتزوج من سعيد ؟ مغامس: ظهر أبو زيد الهلالي. الأم: أبو زيد الهلالي ...... مغامس: من حدثني الساحر عنه .... جاء. الأم: وماذا سيفعل. مغامس: سيحررنا من الملعون سعيد. الأم: وأنت تنتظر من يحررك يا أمير يا ابن الأمير ... أين شجاعتك أين من معيد ....؟ مغامس: يا أمي ... كيف تقولين يا أمي إني جبان. الأم: أنت قلت هذا بأنك تنتظر أبا ميا زيد. مغامس: أبو زيد سيكون عوناً لي ...والنبوءة قالها الساحر. الأم: لا تصدق ككلام الساحر واعتمد على الله ثم على نفسك. مغامس: ليس معي رجال ولا أعوان.

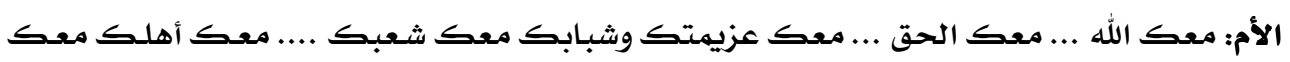

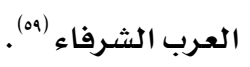

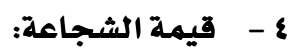

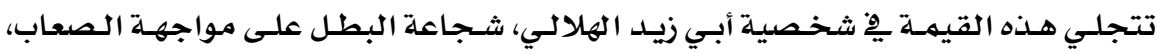

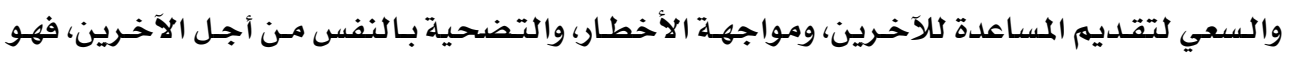

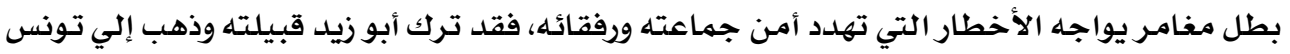
لتخليص الأمير مغامس من ظلهم سعيد الشرير. مغامس: كل هذا المال .... أم مغامس: الحرب تحتاج إلي رجال ومال .... مغلئ مغامس: شكراً يا أمي. أم مغامس: هيا يا ولدي اذهب وجهز ما طلبه منك أبو زيد .. ما دام سيقف بجانبك. مغامس: ألم أقل لك إنه شجاع (.).

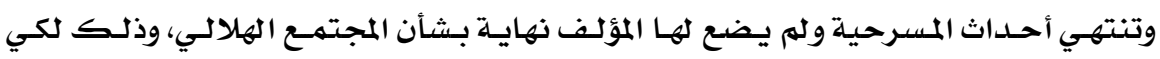

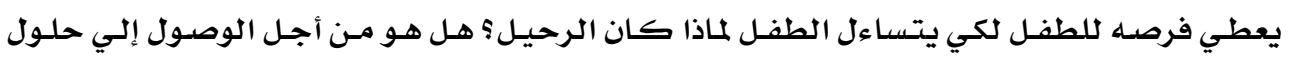




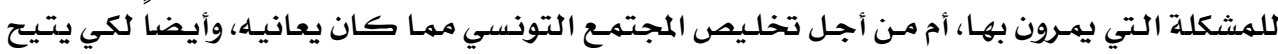

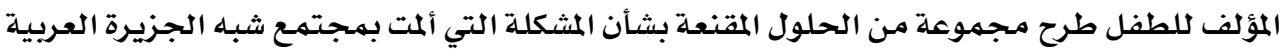

$$
\text { وهي مشكلة (الجوع). }
$$

\section{ثانياً: صورة المجتمع فِ الحكاية الشعبية مسرحية (أولاد جحا) نموذجاً.}

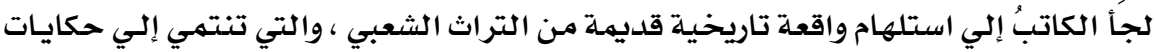

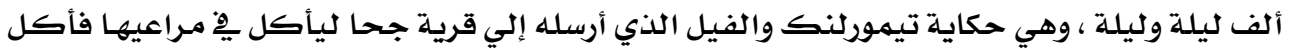

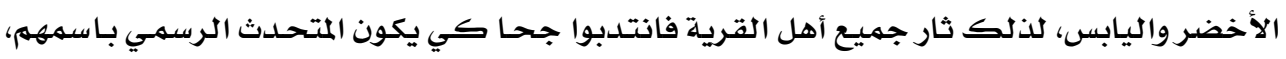

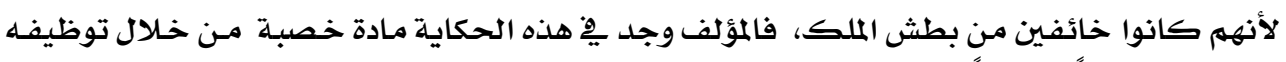

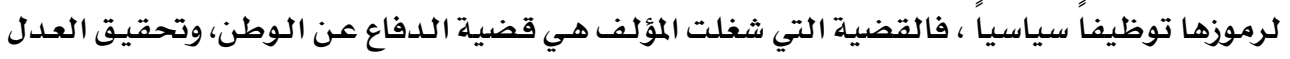

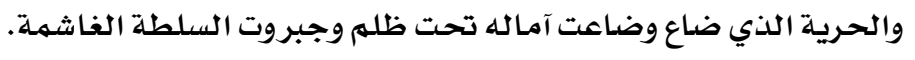

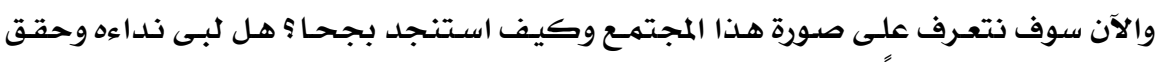
مطالبه أم باعه وباع نفسـه أيضاً

ونجد أن صورة المجتهمع ٌِِ الحكاية الشعبية قد تعددت على النحو التالي:-

$$
\text { 1- صورة المجتمع مسلوب الإرادة (مجتمع سلبي): }
$$

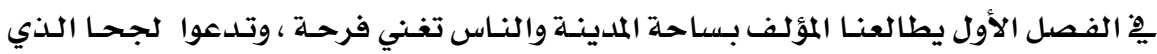
ذهب كي يتحدث مـع تيمورلنـك ليخلصهم مـن الأفيـال ، ويقضي على مشكلة الدمار اليومي الـذي والني

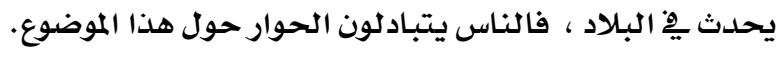
إسماعيل العترة: والله العظيه تلاتة .... أنا قلت ما يجبهاش إلا جحا. فتحي العطار: جحا راجل جدع ...راجل فاهم .. وعاقل.

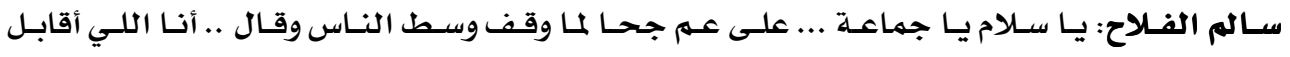
تيمورلنك وأكلمها وأفهمـه.

إبراهيم الترزي: إيه يا جماعة الخير ده.. أنا مصدقتش نفسي إن جحا هيروح بصحيح والله (11).

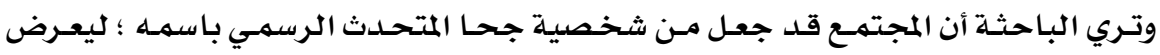

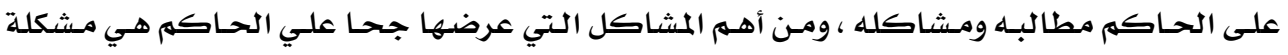

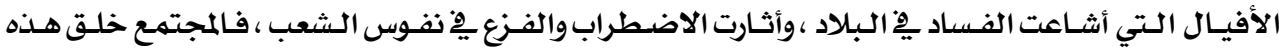

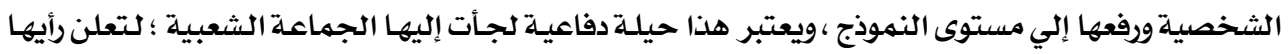

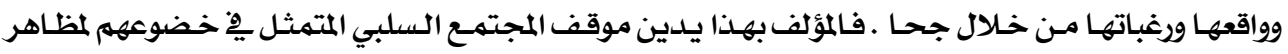

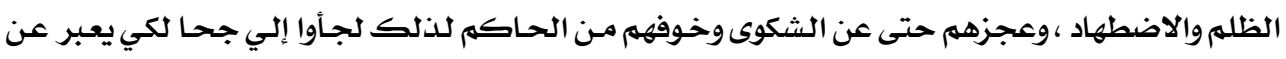




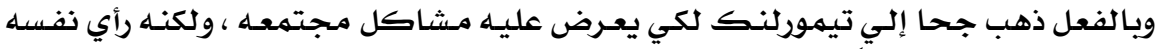

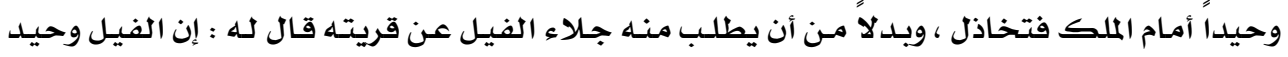

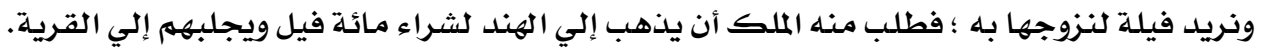
المنادي: (يدخل المنادي يركب على حماريدق الطبل يـا أهـالي البـلاد ... يـا أهـالي البـلاد ... اسمعـوا ... واعوا ... اليـوم قابـل جحـا مولانـا الخاقـان العظيم

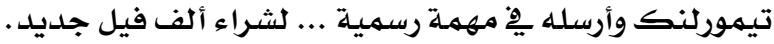

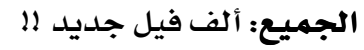
المنادي: أيوه ألف فيل جديل. الجميع: مـين يشتريهم؟

المنادي: يادي وجـع الدماغ ... قلنا ميت مـرة ونقول كمان.

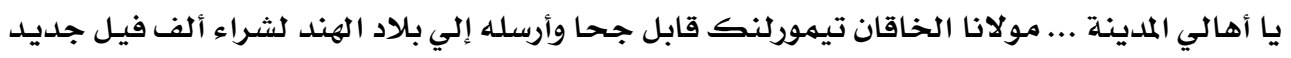

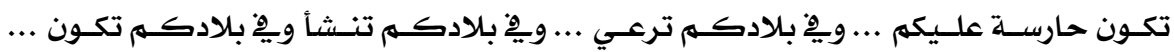
فحافظوا على الأفيال ... جزاكم الله خيرا. إبراهيه: جحا عملها ... جحا عملها .... إسماعيل: جحا بعنا لتيمورلنك... جحا بعنا.

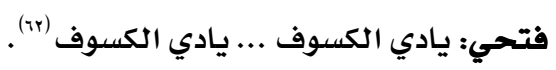

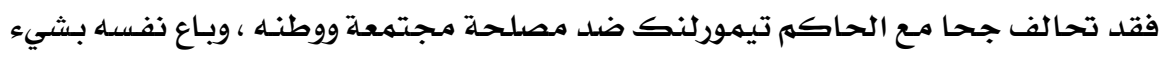

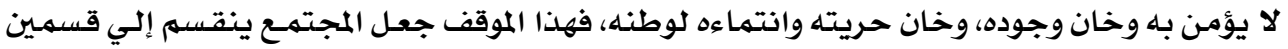

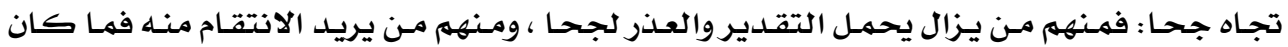

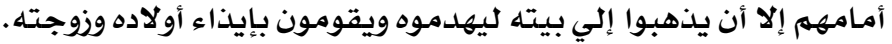

$$
\begin{aligned}
& \text { رجل ا: لازم نهد بيت جحا. } \\
& \text { رجل ب : لازم نهد بيت جحا. } \\
& \text { رجل ب: يسقط جحا الخائن. } \\
& \text { ابن جحا : يا ناس حرام عليكم. } \\
& \text { بنت جحا : يا ناس ارحمونا. } \\
& \text { زوجة جحا : الحقونا. }
\end{aligned}
$$

ابن جحا: (من الداخل) أديني الطشت بتاع الغسيل أغطي بيه رأسي واطلع لهم. زوجة جحا: يا لهوي ... يعوروك يا ضنايا ... تموت يا حبيبي. 
ابن جحا : (يخرج على المسرح وقد وضع على رأسه طشت الغسيل لحماية نفسـه) يا ناس افهموني ... يا

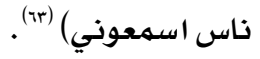

ومن خلال الحوار السابق بالرغمم مـن أن الشعب يريــ الانتقـام مـن أبنـاء جـحـا على مـا فعلـه

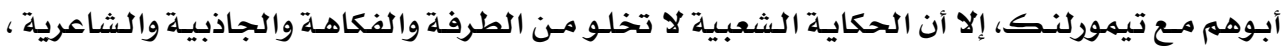

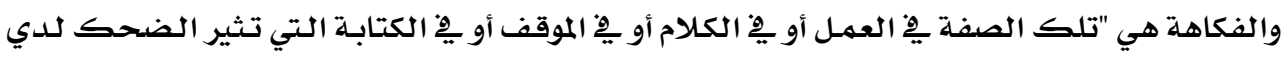

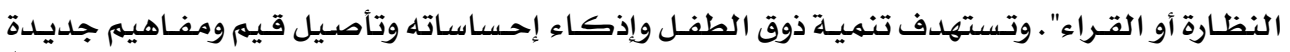

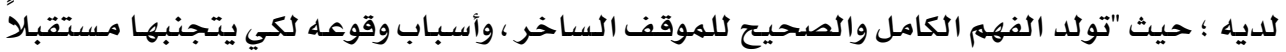

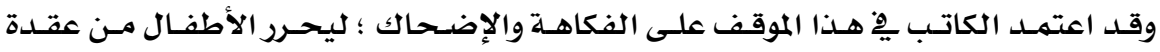

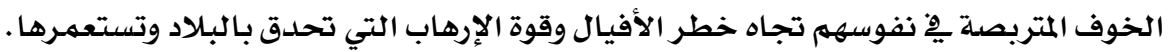

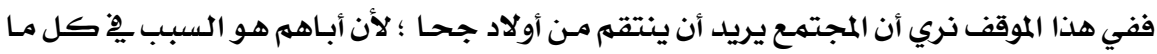

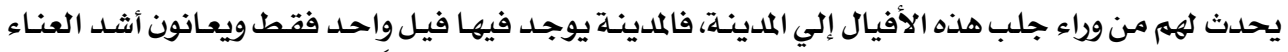

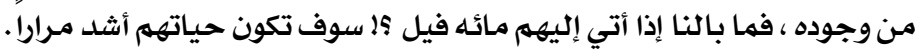

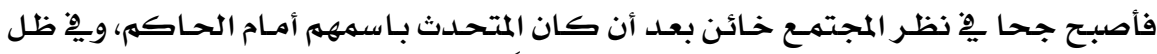

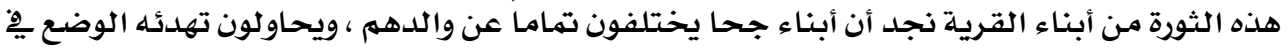

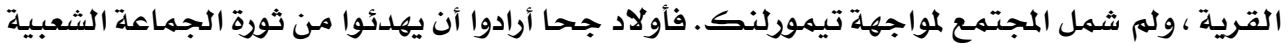

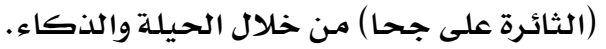
إسماعيل: أبوك راح قصر تيمور وقعد. فتحي العطار: ويقوله على أسرارنا وحكايتنا. زوجة جحا : عارفين إيه اللي جري لجحا. ابن جحا : عارفين إيه اللي جري لجحا. ابن جحا : جحا ... اللي هو أبويا ... وقاله لما سأله تيمورلنك أنا ظالم ولا عادل. المجموعة: قال ... إيه ....؟ بنت جحا : قال لله أنت ملك لا عادل ولا ظالم.... ابن جحا : فالظالمون إحنا .... وأنت سيف العدل ... اللي راح رينا بعته علشان يحقق العدل.

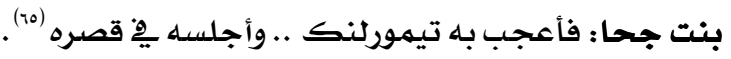

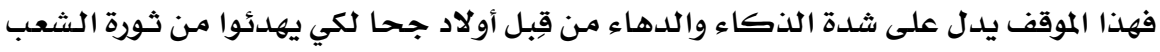

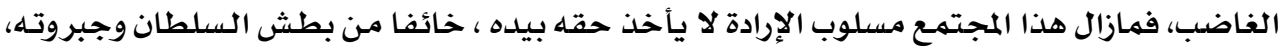

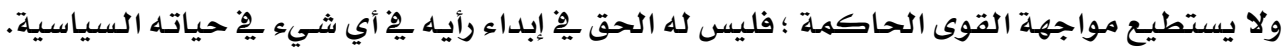


مازال الثائرون عند أولاد جحا يرجونهم كي يحدثوا أباهم ليتوسط لهم عند السلطان ويتضح هـذا

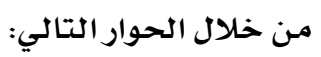

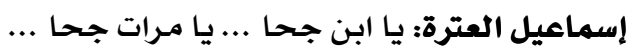

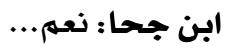
إسماعيل العترة: يا بني ... قول لأبوك يكلم تيمورلنك.

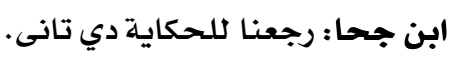
إسماعيل العترة: آه .. الناس خايفة من تيمورلنك . ... خايفة من نفسها ... من الفيل (11).

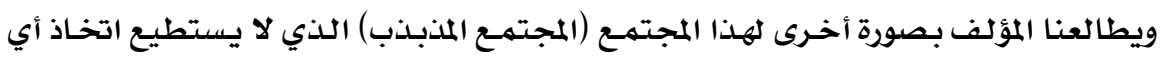

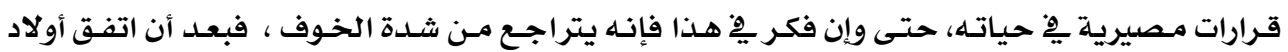

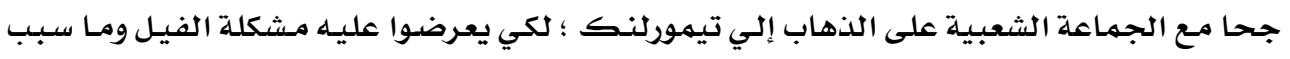

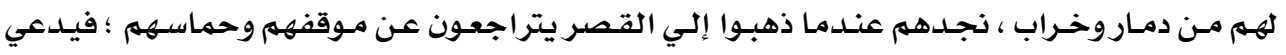

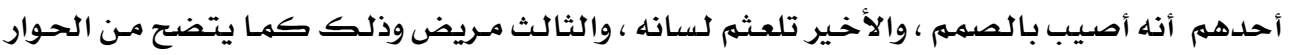
التالي:

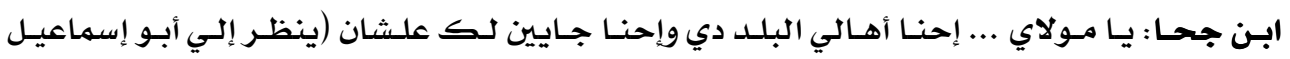
العترة).

ابن جحا: (يهمس يِّ أذن إسماعيل العترة) الفيل. إسماعيل العترة: (يدعي أنه قد أصابه الصمهم) بتقول إيه يا بني ... مش سامـع.

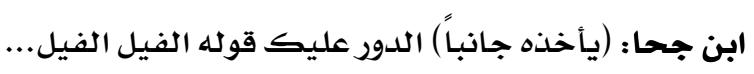

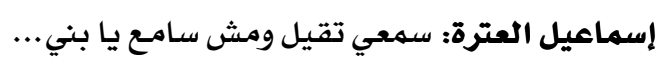
ابن جحا : أبو إسماعيل بيقول الفيل.

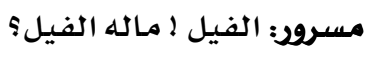

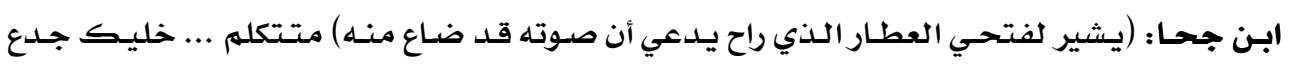
وشجاع.

فتحي العطار: فيلكم يا مولاي ... أهه ... أنا قلت أهه ... وشجاع أنا مش جبان يا بن جحا ... تيمورلنك: متتكله (لإبراهيم الترزي) إبراهيم الترزي: ب....ب... (وهو يرتعش) مدئب لإبراهيم) مسرور: الراجل ده عنده رعشة. إبراهيم الترزي: (يغمي عليه) أنا عندي عيال... تيمورلنك: شيلوه ... وارموه. 


$$
\begin{aligned}
& \text { ابن جحا : لا ... لا ... دا عم إبراهيم الترزي... شيلوه وخلوه على الطريق. } \\
& \text { مسرور: وأنت (يشير لزيدان الحطاب) أنت يا حلو ... ناقصك شيء عايز شيء ألئرئ } \\
& \text { زيدان: (يهسك بطنه) عندي إسهال يا مولاي أعفيني من الكلام طلعني الآن (يخرج) } \\
& \text { ابن جحا: وأنت يا دنوش يا نجار. } \\
& \text { دنوش النجار: يا أبو قلب طيب... يا كبير .. إنسان ... أنا دماغي سخن. }
\end{aligned}
$$

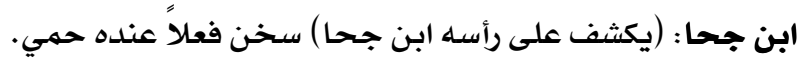

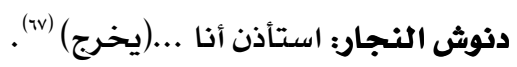

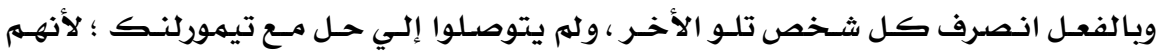

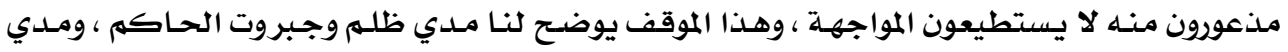

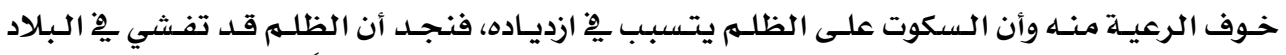

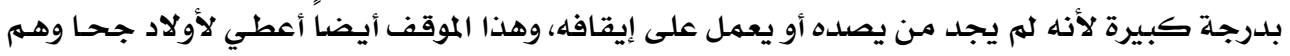

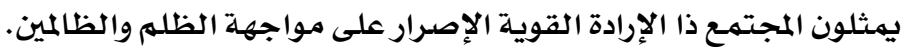

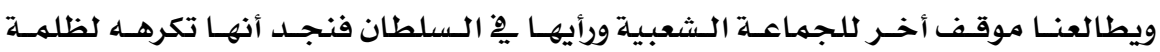

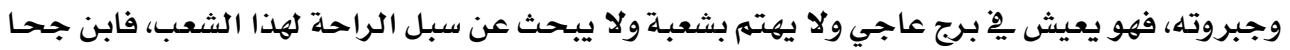

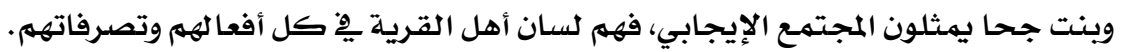
بنت جحا : أنت مقامك يِّ الآخرة مـع الظالمين فتذكر الموت بأنه يأتي من غير ميعاد. تيمورلنك: بتقولي إيه يابنت؟

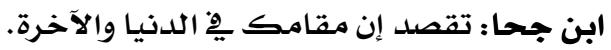

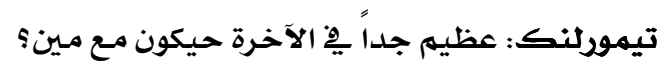
ابن جحا: مـع .... مـين إزاي.... تيمورلنك: ح أكون مـع مـين من العظماء؟ مسرور: قول ....

$$
\text { تيمورلنك: فرعا : مـ فرعون. }
$$

وتري الباحثة أن تيمورلنك سُر بهذه المكانة ؛ لأنه سوف يكون مـع العظماء من أمثالـة، على

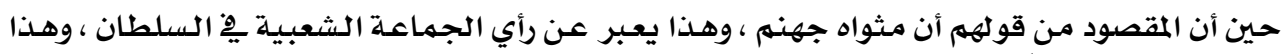

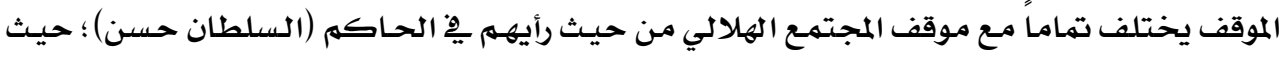

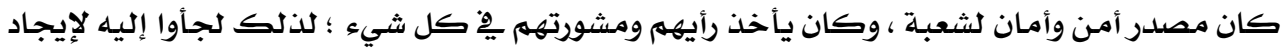

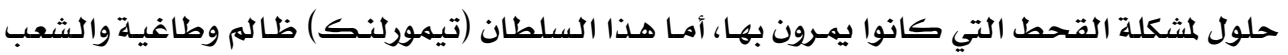




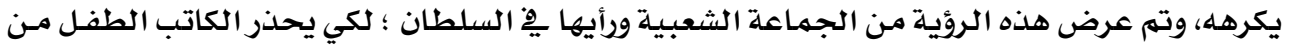

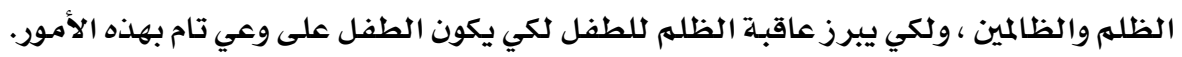

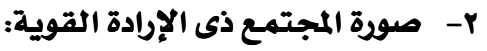

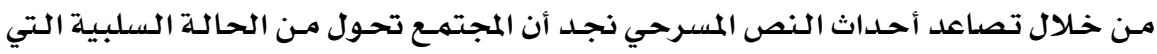

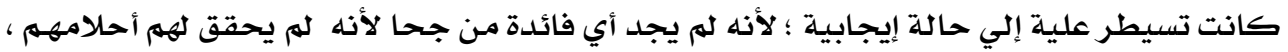

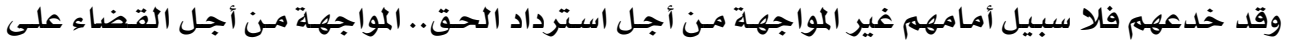

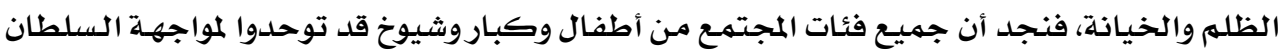

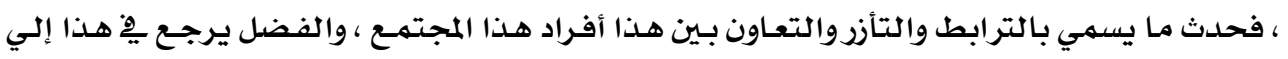
أولاد جحا والشيخ شافعي. الشيخ شافعي: إحنا كلنا لازم نحل المشكلة إحنا. الجميع: إحنا.

الشيخ شافعي: آه .. المشكلة تخصكم كلكم وكلكم لازم تحلوها من الصغير للكبير. ابن جحا : زي ما قال الشيخ شافعي كلنا لازم نكلم تيهورلنك. بنت جحا : كلنا من صغيرنا لكبيرنا والصغير قبل الكبير ستات ورجالة (19).

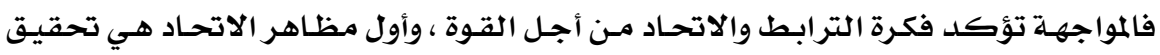

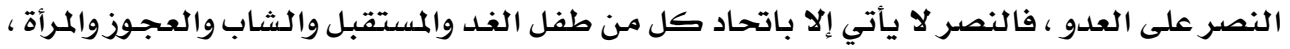

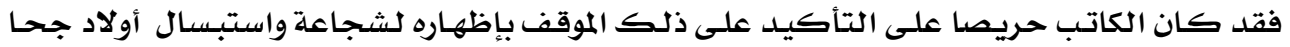

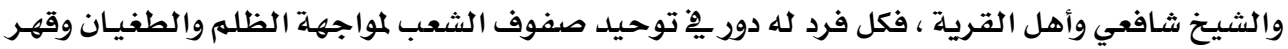

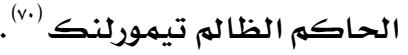
ومن خلال مكر ودهاء أولاد جحا استطاعوا كسب ود السلطان ؛ فتم تعيين ابن جحسا وزيـرا

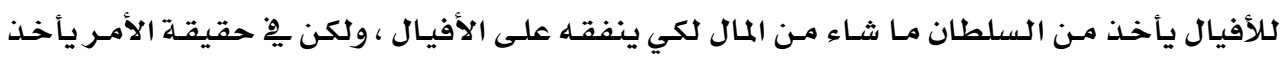

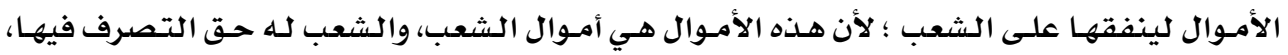

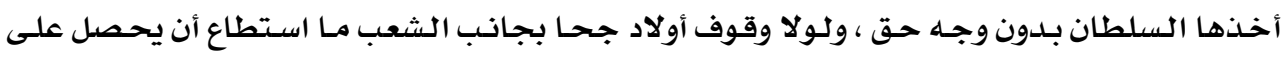

بنت جحا : أخويا هو الوزير اللي يِّ عهده صارت المدينـة ثرية وجميلة وغنية. ابن جحا: (يدخل على المسرح) (ابن جحا يِّ ملابس جميلة).

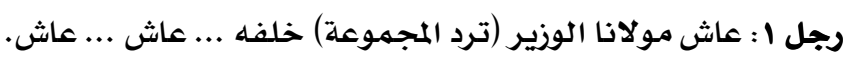
ابن جحا : أشكركم أشكركم .... كيف الحال يج السوق وكيف حال البلاد؟ الجميع: بخير بخير. ابن جحا : عايزين فلوس قولوا (يخرج النقود ويلقي بيها يميناً ويساراً). 


$$
\begin{aligned}
& \text { بنت جحا : (تجذب أخاها بعيداً) بتعمل إيـه } \\
& \text { ابن جحا : بوزع فلوس زي ما أنت شايفة. } \\
& \text { بنت جحا : كل يوم تاخد ألف دينار...وتوزعهم؟! }
\end{aligned}
$$

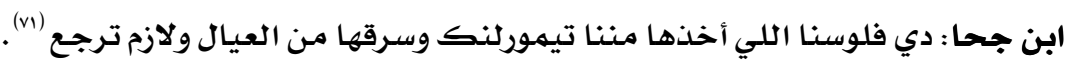

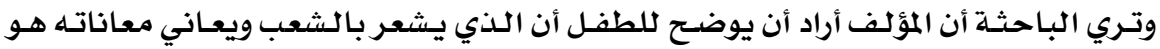

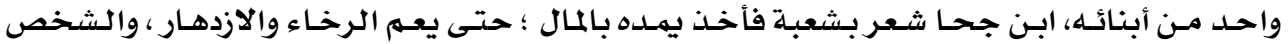

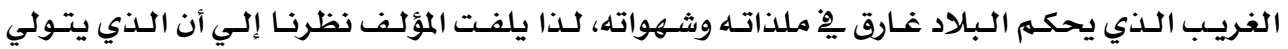
السلطة لابد أن يكون واحدا من أبناء الشعب حتى يحقق ما يصبوا إليه الشعب.

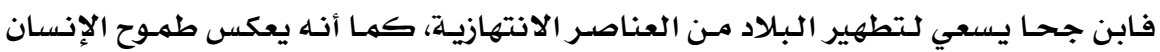

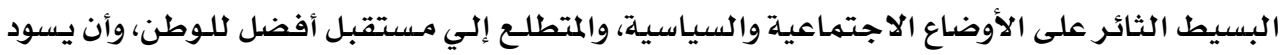

العدل والحب والمساواة داخل هذا الوطن الاوفاعن.

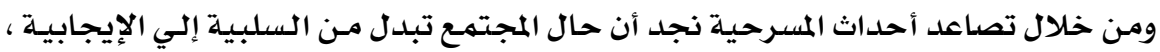

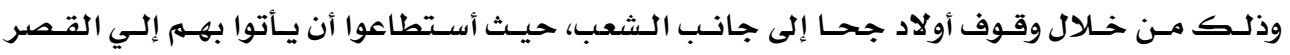

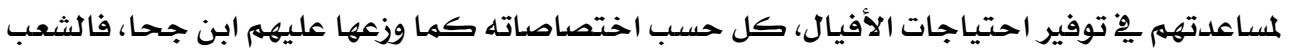

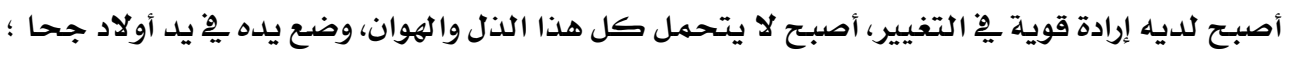

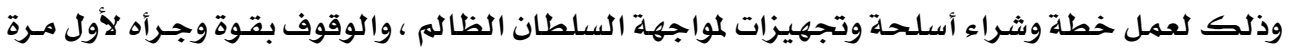
هِِ وجه هذا السلطان وتطهير البلاد من العناصر الانتهازيـة. إبراهيم الترزي: اشترينا أفضل الأكل وأفضل السلاح ودربنا الناس. سالم الفلاح: إحنا مرتبين كل شيء والرجالة على استعداد.

$$
\text { بنت جحا : وطي حسك... الناس لازم تتعلم على السلاح. }
$$

ابن جحا : يا بنت جحا كفانا خوف... لازم تيمورلنك يعرف إننا قده وقدود.

بنت جحا : علشان لما تيجي ساعة الجد كل الناس ستكون جاهزة للقتال..

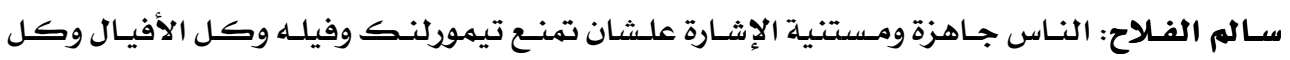

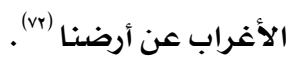

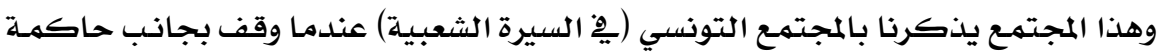

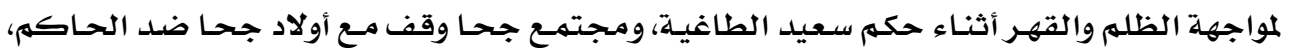

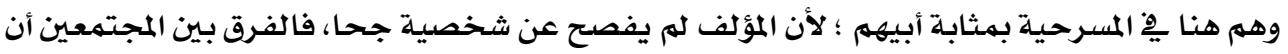

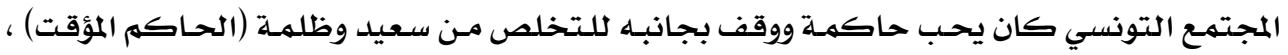

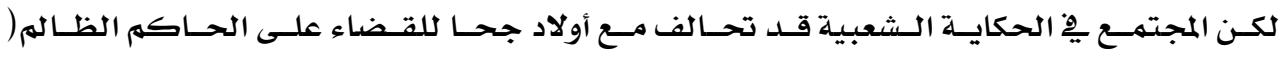
تيمورلنك). 
وبالفعل استعد الشعب لمواجهة تيمورلنك والأفيال.

الشيخ شافعي: آن الأوان تتجمع الأيادي والعباد.

فتحي العطار: إحنا درينا الرجال على القتال.

بنت جحا : والستات عرفت حتعمل إيه ...

الشيخ شافعي: الكل عرف حيعمل إيه حتى الأطفال عرفت حتعمل إيه؟ إبراهيم الترزي: وساعة الجد....

فتحي العطار: ساعة الجد إمتي....؟

الشيخ شافعي: أول ما يوصل جحا ومعاه الأفيال حيكون الصيادين على الشط يغرقوا المراكب بالأفيال.

بنت جحا : وأبويا.

الشيخ شافعي: متخفيث بعد ما ينزل كل الرجال حتغرق المراكب بالأفيال.

فتحي العطار: وحضرنا السلاح.

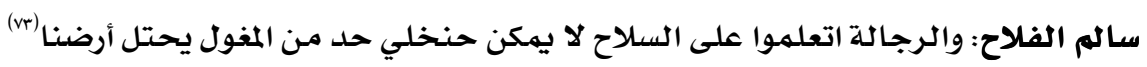

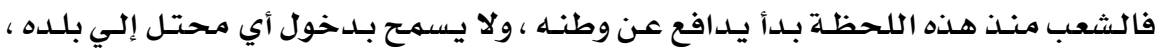

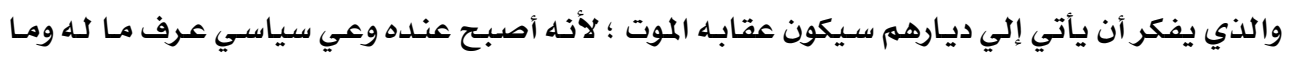

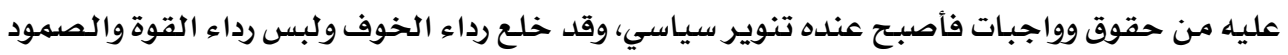
والعزيمة والشجاعة.

فالكاتب يهدف الى تكوين جيل متمـرد ثائروقادر على استتصــال الظلهم وتطهير البلاد مـن الفساد،

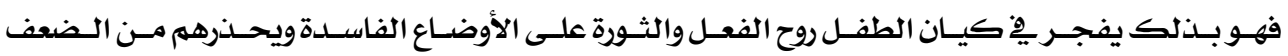
والاستكانة.

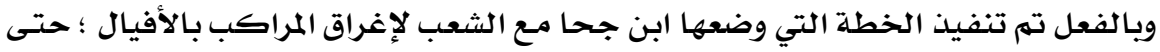

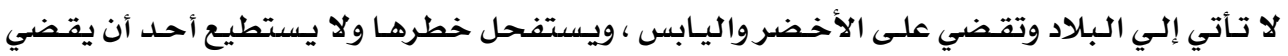
عليها. حارس: (يدخل مسرعاً جحا وصل يا مولاي على الشط). تيمورلنك: والأفيال معاه ... ألف ألف فيل الحارس: لا يا مولاي ... المراكب غرقت بالأفيال قبل ما تدخل الميناء. تيمورلنك: مش معقول ألف ... ألف فيل يغرقوا مين اللي عمل كـده سالم الفلاح: (المجموعة والشيخ شافعي) كلنا ... كل الناس (vأ.

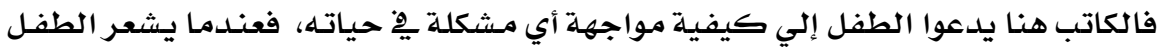

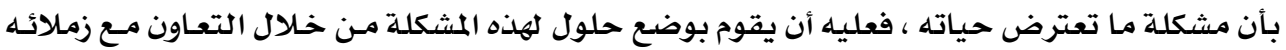




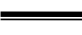

أو أخذ رأي أبويه ٌِِ هذه المشكلة ووضـع حلول لها، ليقضي عليها يِّ أقرب وقت ولا يتركها تستفحل ؛ لأنها إذا استفحلت سوف تكون هنالك صعوبة يو فيخ حلها.

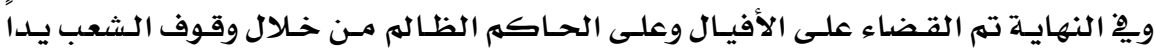

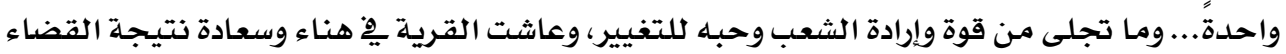
على الظلهم والظالمين. الشيخ شافعي: ِِّْ زمن من غير رجال تكثر الأفيال .. خلِي بالكم يـا ولاد لو خفنـا مـن الأفيال راح تكثر

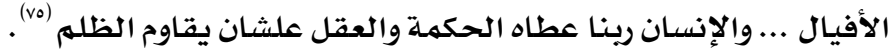

أهم القيم التي طرحها السيد حافظ بِ مسرحية (أولاد جحا)

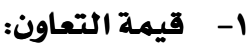

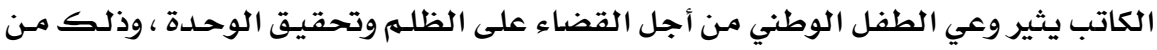

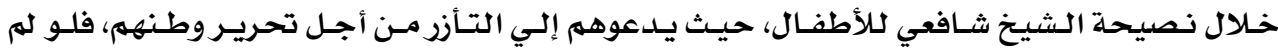

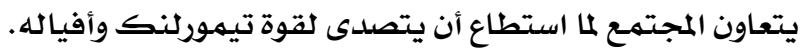

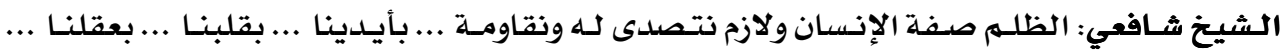
والناس تمد إيدها (vi)

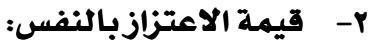

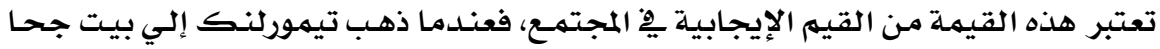

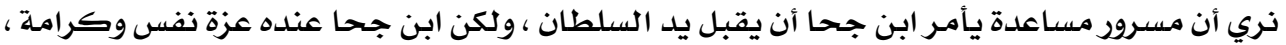

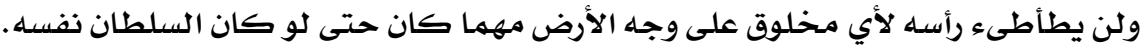
مسرور: انحن ... انحن يا ولد ...وقرب ويوس إيد مولانا تيمورلنك. ابن جحا: ابلا. تيمورلنك: لأ ليه ( يغضب) الولد دا يقتل هِ الحال. بنت جحا : لا يا مولاي ... مش معقول ؛ أخويا خاف على إيدك اللي لا تقدر بالمال (vv). r- م- ق بمة الحكمة والتصرف بعقلانية:

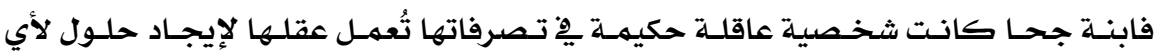

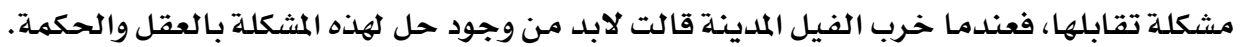

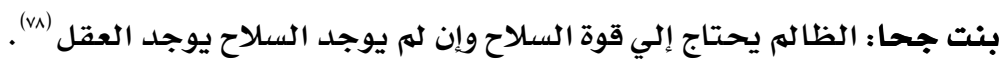
ع- قيمة الجيرة:

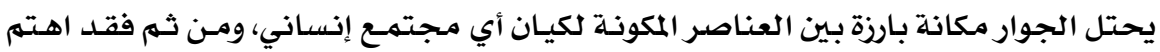

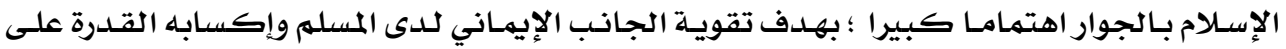




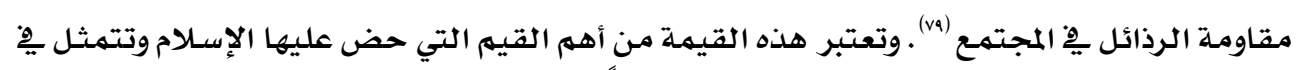

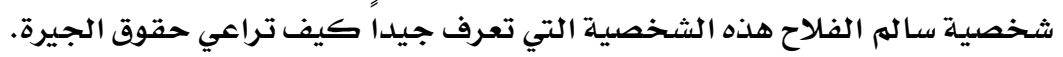
بنت جحا : الفلاح دا يا مولاي طول عمرة جارنا ويراعي حقوق الجيرة والأخوة (.A).

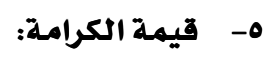
هذه القيمة تتمثل ِِ شخصية بنت جحا حيث أنها ترفض الزواج مـن الحـاكم تيمورلنـك

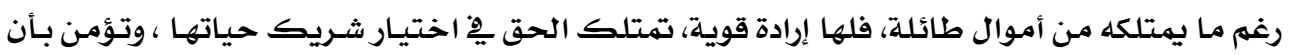

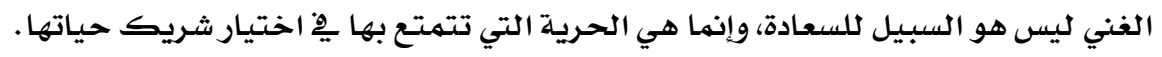
بنت جحا : أنا لا يمكن اتجوز راجل زي داء زوجة جحا : دا مكتوب علينا. بنت جحا : دا ظاله وقاتل...

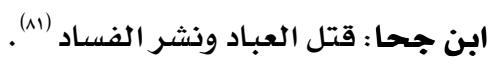

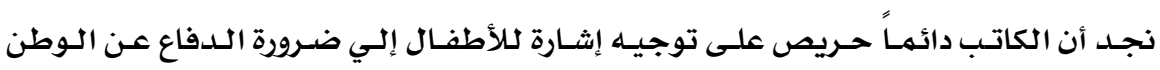
7- قيمة الانتماء وحب الوطن:

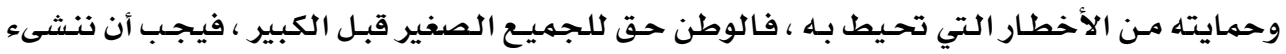

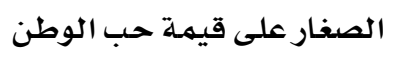

الشيخ ثـافعي: الدفاع عن الوطن شرف ولازم ندافع عن شرفنا (ri) .

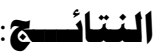

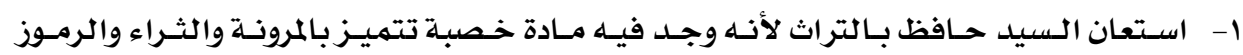

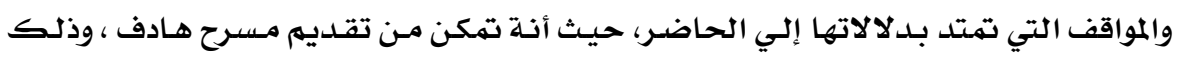

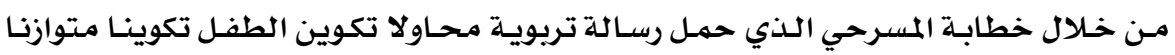

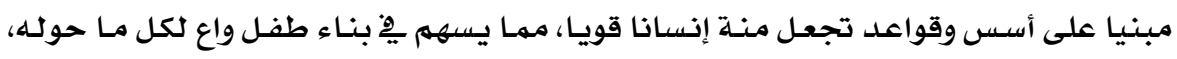

$$
\text { مستوعب لواقعة. }
$$

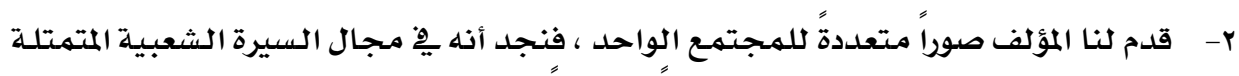

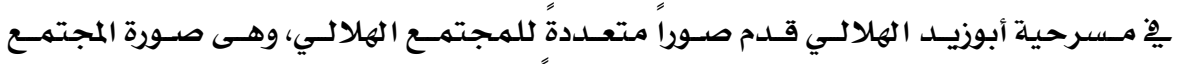

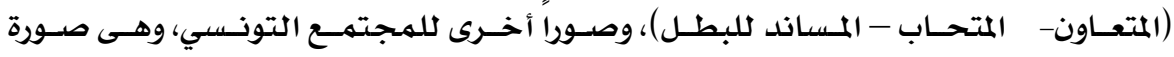

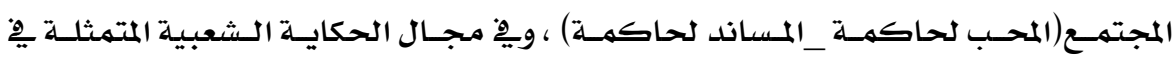

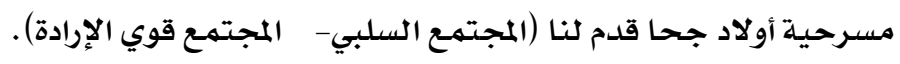

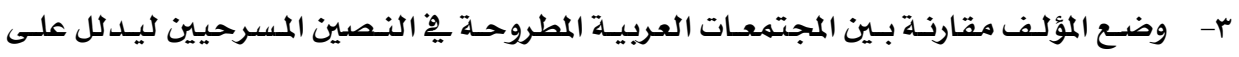

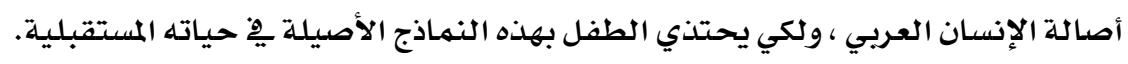

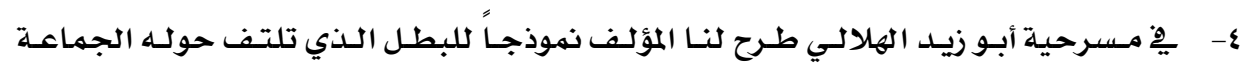




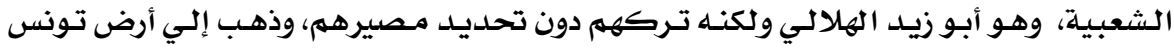

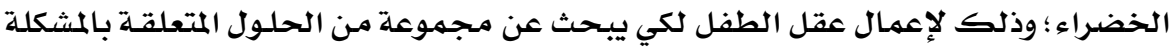

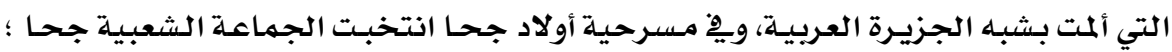

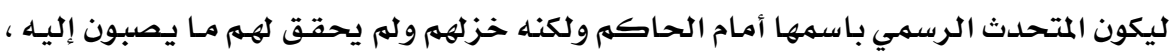

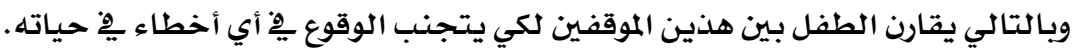

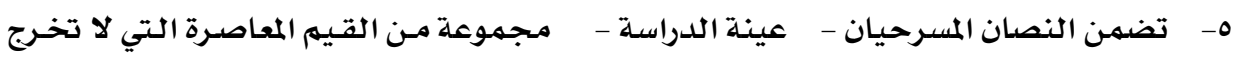

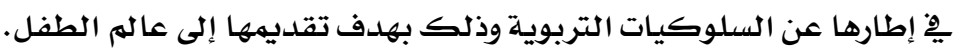

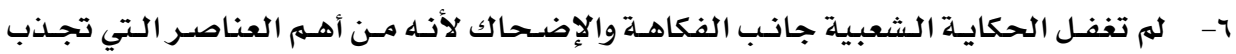

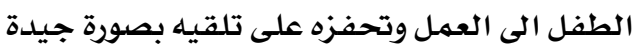

1- ضرورة عمل دراسات مستفيضة حول أعمال هذا الكاتب بصفة خاصة لتوضيح ما بها من قيم

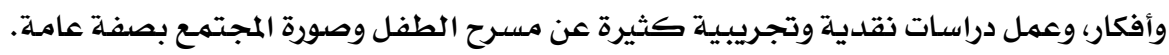
r- ضرورة تشجيع كتاب المسرح لكتابة مسرحيات للأطفال تلقي الضوء على تراثنا وحضارتنا

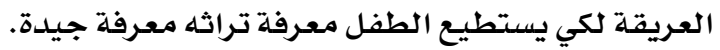

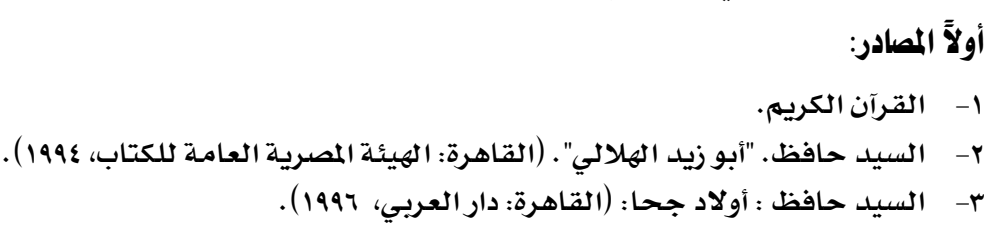

ثانياً: المراجع: الميد حافظ

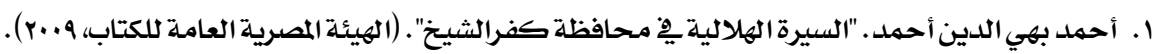

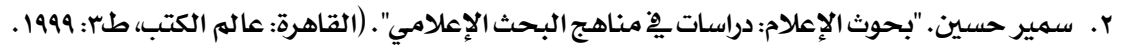

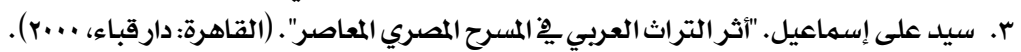

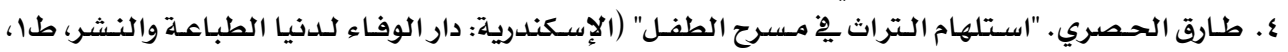
(r...v

ه. عبد التواب يوسف. "الطفل العربي والأدب الشعبي". (القاهرة: الدار المصرية اللبنانية، 1991).

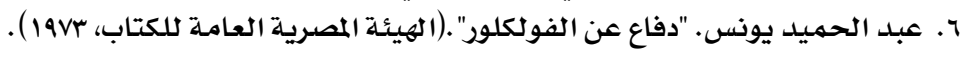

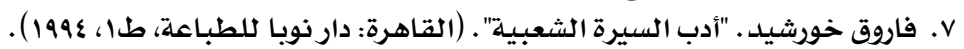

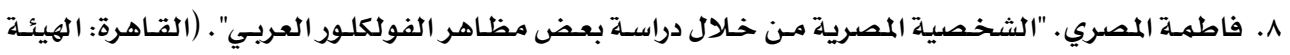

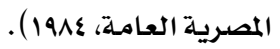
9. كمال الدين حسين. "التراث الشعبي يِّ المسرح المصري الحسديث". (القـاهرة: الدار المصريـة اللبنانيـة، طا، . (1994

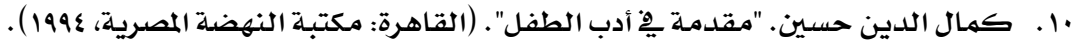

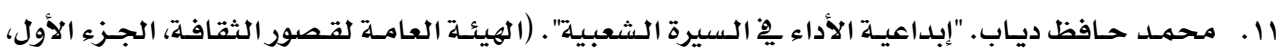
.$(1990$ 


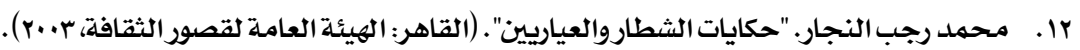

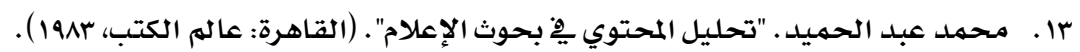

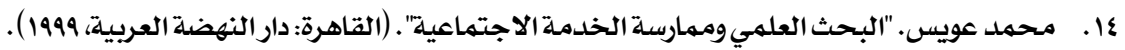

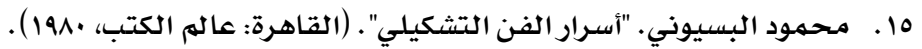

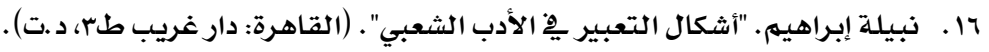

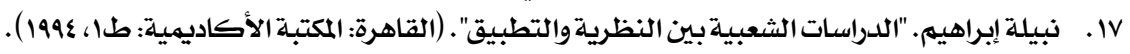

\section{ثالثاً:البحوث السابقة:}

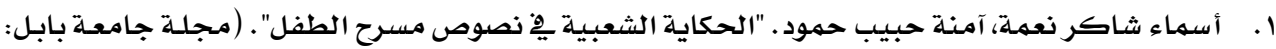

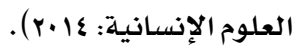

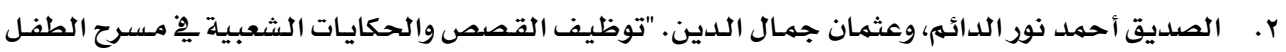

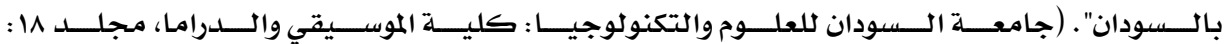

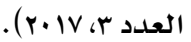

r. عزة الملط ."المستلهم التراثي والمتغير الحداثي يِّ مسرح الطفل" . (مجلة كلية دار العلوم: جامعـة القـاهرة،

$$
\cdot(r \cdot 10
$$

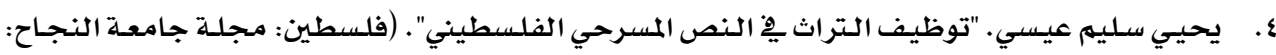

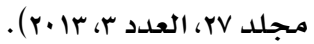
ه. يحيي سليه عيسى، عدنان على المشاقبـة. "آليـات توظيف التراث يِّ النص المسـرحي الإمـاراتي وكيفياته:

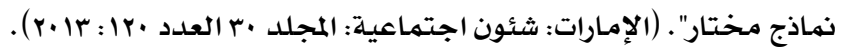
رابعاً: الرسائل العلمية:

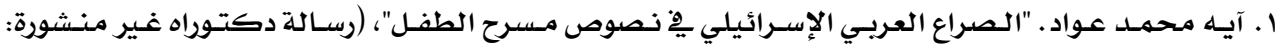

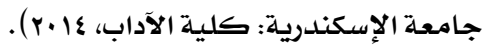

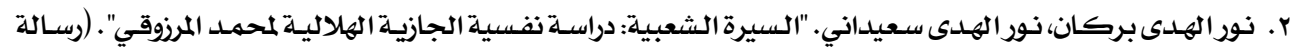

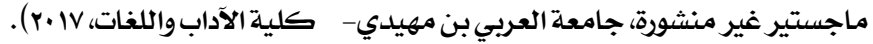

\section{خامساً: السلاسل والدوريات:}

ا ـ صفوت كمـال. "الحكايـة الشعبية ِِِ مجـال أدب الأطفـال، مجلـة الفنـون الشعبية العـدد هب، (وزارة الثقافة:

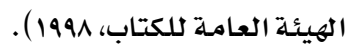

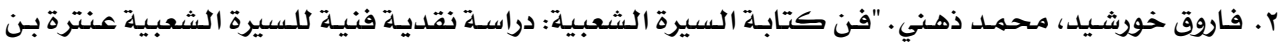

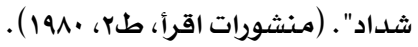

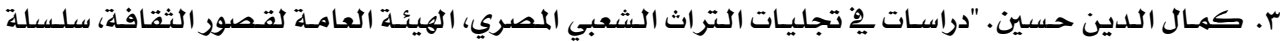

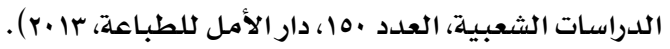
سادساً: مواقع الانترنت:

1- https://drige.google.com.

2- Https://archive.islamonline.net. 


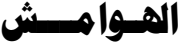

(')https://drige.google.com.

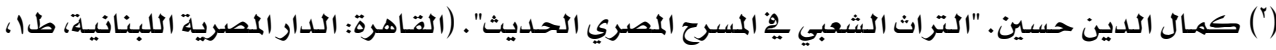
.$(1994$

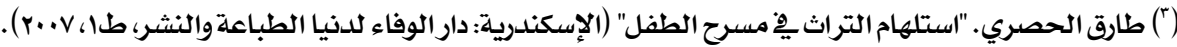

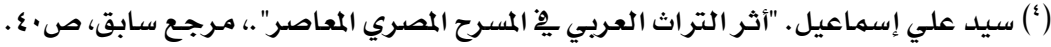
( ) طارق الحصري. "استلهام التراث ِِّ مسرح الطفل" . مرجـع سـابق.

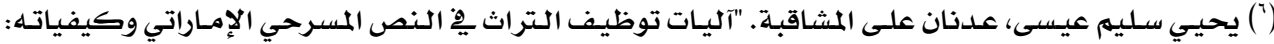

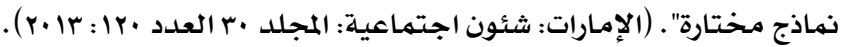

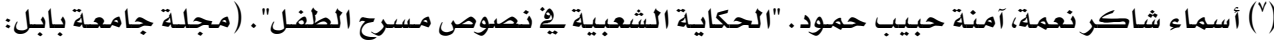

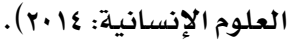

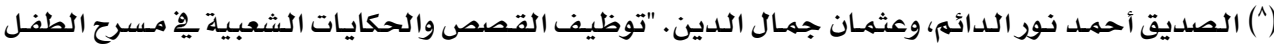

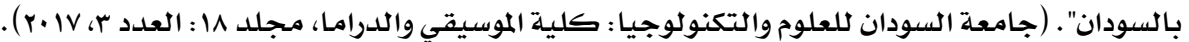

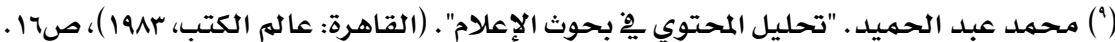

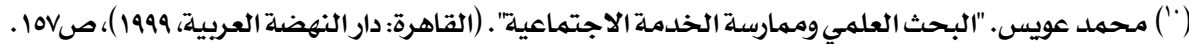

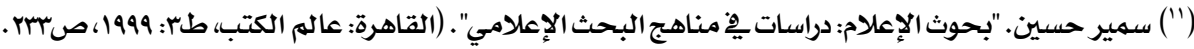

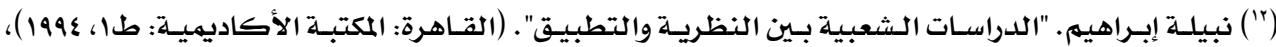

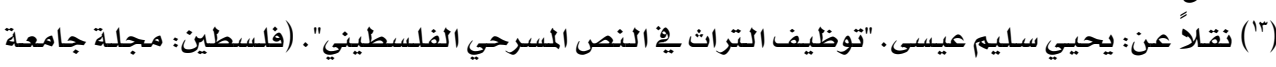

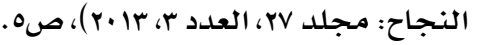

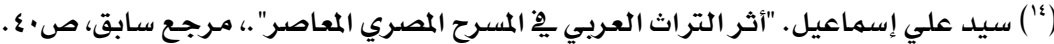

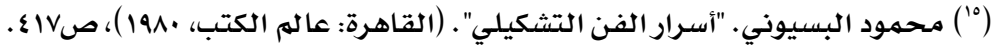

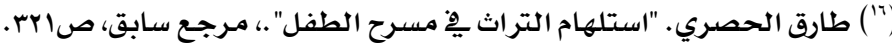

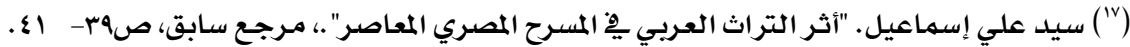

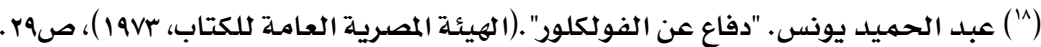

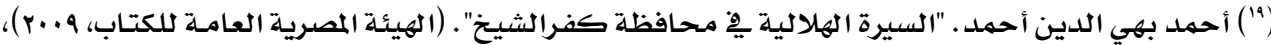
صr.

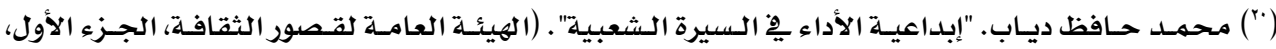

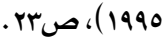

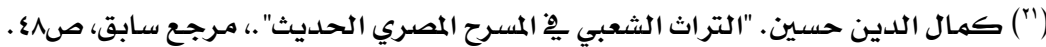

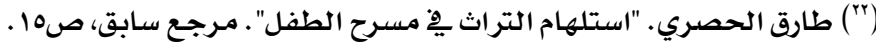

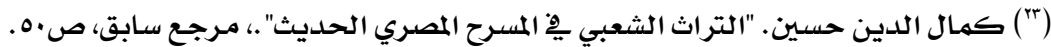

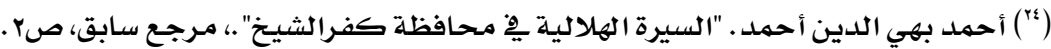

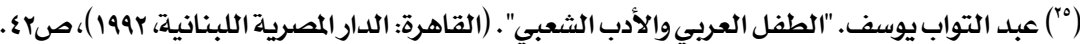


(T) نور الهدى بركان، نور الهدى سعيداني. "السيرة الشعبية: دراسـة نفسية الجازيـة الهلاليـة لمحمد المرزوقي".

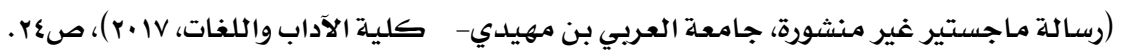

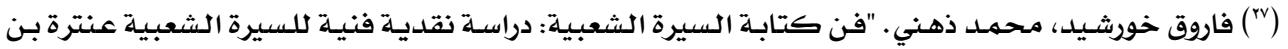

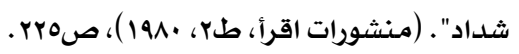

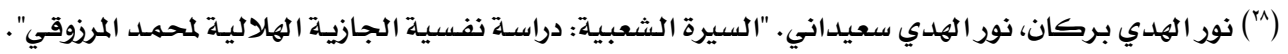

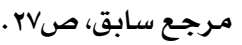

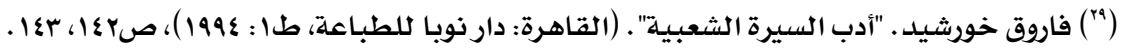

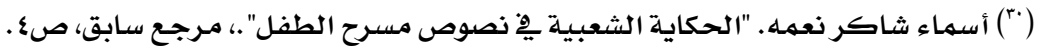

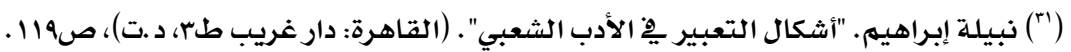

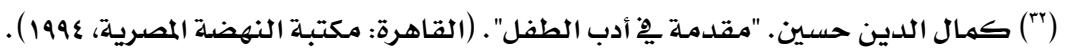

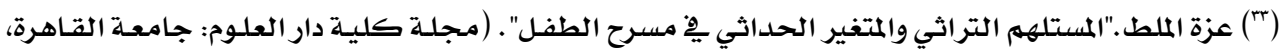
(r)

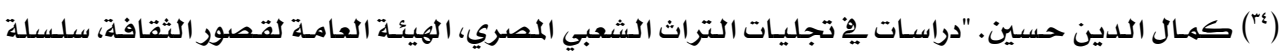

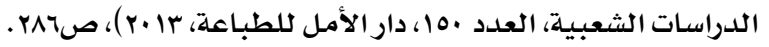

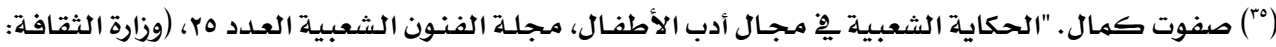

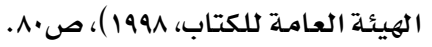

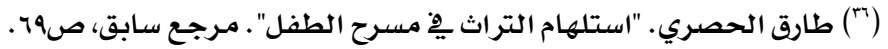

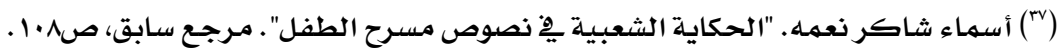

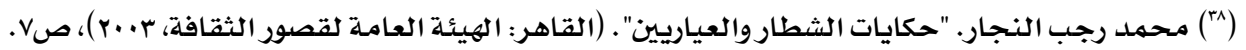

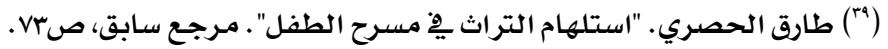

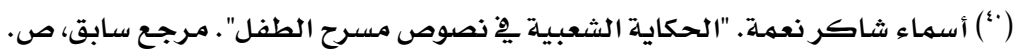

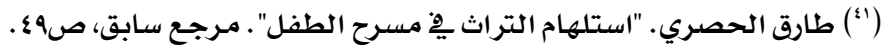

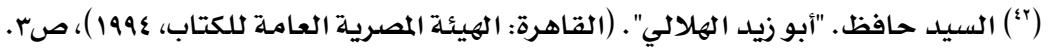

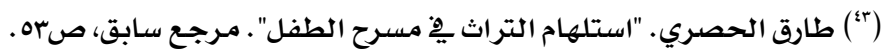

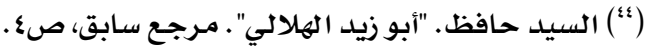

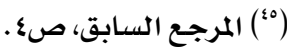

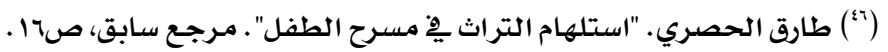

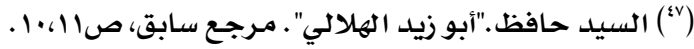

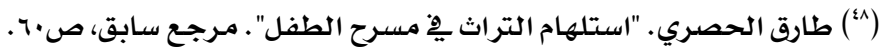

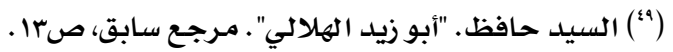

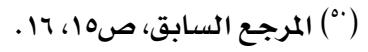

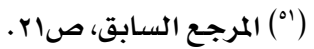

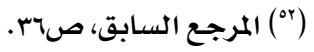

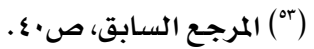




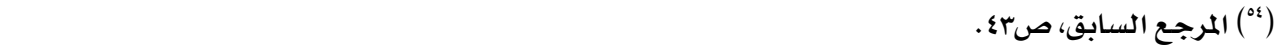

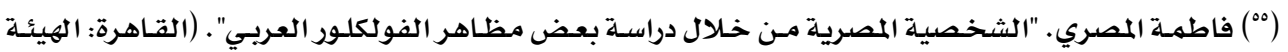

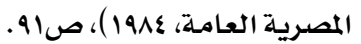

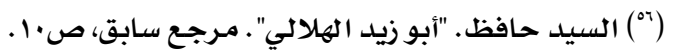

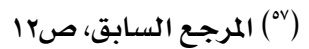

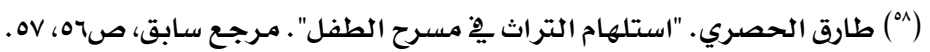

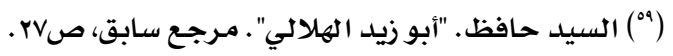

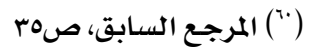
(") السيد حافظ : أولاد جحا : المرجي، دار العربي، 1997، صهـ.

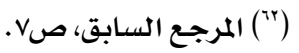

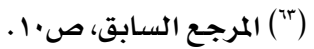

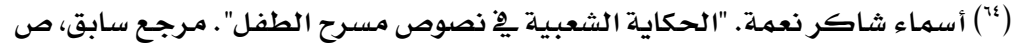

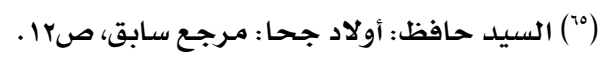

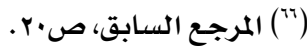

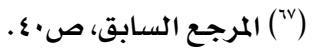

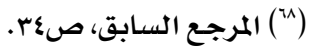

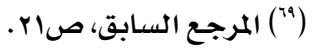

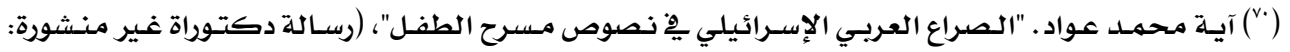

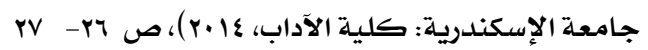

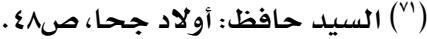

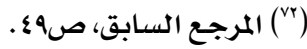

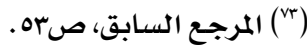

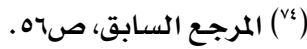

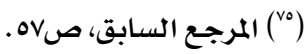

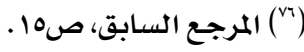

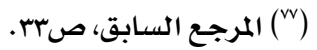

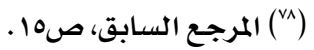

( $\left.{ }^{\left({ }^{q}\right.}\right)$ Https://archive.islamonline.net.

$$
\begin{aligned}
& \text { (^) المرجـع السـابق، صه0. }
\end{aligned}
$$

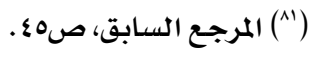

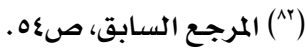




\section{The Image of Community in the Texts of Children's Theatre As Illustrated}

\section{by the Writings of Sayyed Hafez}

\section{Abstract}

- Research Problem: The Problem of this research is represented in the answer of the following question: What is the image of the community in the texts of children's theatre as illustrated by the writings of Sayyed Hafez?

- The Importance of Research: The importance of this research is attributed to its focus on building up an image for the community from a heritage-based perspective, being popular folktales or popular story-telling, and introducing this image to the world of children.

- Research Objectives: The research aims to identify the image of the community in the texts of children's theatre as illustrated by the writings of Sayyed Hafez.

- Research Type and Approach: It is a content analysis, descriptive research.

- Method of Selecting the Sample: The researcher selected the two theatrical texts using the intentional method.

- Research Sample: The research sample consists of the two theatrical texts: "Abu Zaid Al-Hilali" as a sample for the popular folktales and "Awlad Joha" (Sons of Joha) as a sample for the popular story-telling by Sayyed Hafez.

- Research Time Limits: 1994-1996

- Research Results:

- Sayyed Hafez utilized heritage as a fertile area characterized by flexibility, richness, and situations that extend to indicate the present.

- The author introduced multiple images for the same community. That is, in the field of folktales, the image of the (cooperative, hero-supporting, and ruler-loving) community is presented, while the image of the (negative, strong-willed) community is presented in the field of popular story - telling. This proves that the image of the community presented in the popular folktales is obviously different from that presented in the popular storytelling.

- The two theatrical samples of this study include a set of contemporary values that fall within the domain of educational behaviors to be introduced to the world of children. 